\title{
LA ESCULTURA FUNERARIA EN LA NUEVA ESPAÑA
} $\mathbf{P} \mathbf{R}$ MANUEL,TOUSSAINT

H AÇE algún tiempo el señor don Manuel Romero de Terreros publicó 1 un breve estudio acerca de la escultura funerariz en la Nueva Espafia. ${ }^{1}$ Comienza lamentándose de la pobreza de dicha escultura sin explicarse los motivos que pueden haber originado tal penuria; sigue reseñando los ejemplares de estatuas que han llegado a su conocimiento y termina declarando que todas las obras de este género producidas en México son poco menos que pésimas.

Es indudable que la escultura funeraria de la Nueva Espatia no puede compararse ni con mucho con las magnificas obras de igual fndole que existen en la Metrópoli: Varias causas pueden aducirse para ello. Desde luego el Primer Concilio, efectuado en México en 1555, prohibe; eri uno de sus estatutos, que las sepulturas que se hagan en las iglesias se levanten del suelo y en otro que vendan o alquileri sepulcros. De manera que de he-

1. Arte Coloniali Teneern nerie. México, 1921. Paga: 63 a 77 . 
cho prohibe toda clase de sepulturas, excepto las llamadas laudes. Por otra parte, en un pais recién convertido al catolicismo, no debe haber parecido conveniente la abundancia de figuras de laicos en el interior de los templos al lado de los santos a quienes se veneraba. Por eso todas las esculturas que conservamos son estatuas orantes: representan a un fiel que está en oración.

A pesar de todo to dicho, es indudable que la escultura funeraria no fué tan escasa como se piensa, que muchas obras fueron destruídas posteriormente, pues como las iglesias sufrieron por lo menos dos reconstrucciones $y$ las esculturas provenian del patronato o, mejor dicho, del vicepatronato, obtenido por limosnas para la obra, al desaparecer el monumento para edificar otro cesaba de hecho el compromiso por el cual se había colocado la estatia.'

Revisando nuestras noticias y las ilustraciones que hemos podido obtener, nos decidimos a publicar un nuevo ensayo sobre el mismo tema, en vista de que nuestras informaciones son más numerosas que las del señor Romero de Terreros y lo mismo la parte de ilustraciones que en su trabajo casi es nula. Nosotros reproducimos todas las estatuas que conocemos, que ascienden al número de trece. Es posible que existan en algunas iglesias de provincia esculturas que han escapado a nuestras búsquedas, pero creemos que lo fundamental está descrito en el presente ensayo. Al lado de aquellas obras que conservamos, existen las informaciones de esculturas hoy desaparecidas. Es conveniente reproducir las noticias que acerca de ellas nos quedan y, además, en todos los casos, dar la noticia de los persơnajés representadó en las esculturas, en forma sucinta pero precisa, cuando esto sea pósíble.

Data de tiempios inmemoriales el afán de lös hombres por perpetiar su imagen desptrés de muertos. Parece que no es un simple impulso de vanidad el que mueve a tantos seres a desear persistir en forma material en la tierra anano sus cuerpos han desaparecido. Dijérase que, al lado de la inmortalidad del alma, ellos deseat; por lo menos; la persistencia humana de su figura. Desde los viejos faraones egipeios que sobre el sarcófago que cubría su momia procurpban reproducir fielmente los trazos de su rostro, hasta aquella buena anciana de Génova, cuya efigie todavia contemplamos en el cementerio de esa ciudad, aquella que pasó $\mathbf{s u}$ vida vendiendo roscas con el único objeto de reunir el dinero necesario para que a su muerte reprodujeran su persora con sus queridas roscas, vendiéndolas a la eternidad, 
pasando por la serie de retratos pontificios que encontramos en la Basílica de San Pedro en que el arte se encuentra a veces a merced del orgulło, y por aquellas estatuas inmortales de los Médicis en que el genio de Miguel Angel perpétuó las figuras de los dos caballeros, ennobleciéndolós si era posible -y sí lo fué- con el soplo privilegiado del arte, el mundo se encuentra lleno de figuras que representan seres desaparecidos. Al lado del retrato que capta la vida que el artista encuentra en su modelo, estas obras representan a los hombres en la actitud postrera de su existencia. No hay, como decía yo, estatuas yacentes en la Nueva España, por lo. menos en las que conocemos; quizá se hayan hecho algunas en el siglo XvI ; todas representan a personajes que rezan, como si la plegaria fuese un podér misterioso que prolongase la vida en actitud de elevación y fervor. Otra característica de la escultura funeraria en Nueva España es que en ella abundan las figuras hechas en madera policromada y son pocas las de piedra o mármol. Esto puede explicarse por el afán realista de la imaginería colonial que trata de reproducir a los seres con sus propias facciones, sus propios colores, su propio espíritu. El mármol y la piedra resultan fríos esqueletos en que la vida no gusta de anidar. Los ojos de una estatua de mármol son ojos muertos aunque el escultor haya procurado darles vida. Al lado de la magnifica estatuaria española, de tantos reyes y principes y nobles, tendidos en sus ricos sarcófagos renacentistas, o de rodillas en nichos platerescos o barrocos, la estatuaria mexicana presenta un aspecto casi popular. Al señor Romero de Terreros le parecen detestables todas las estatuas que describe. Con un criterio menos académico puede encontrarse en las láminas que a continuación se reproducen, por una parte la ingenuidad del esaultor, por otra la sencillez de la actitud o el detalle pintoresco, tan hejano del fin de la obra, como en las estatuas de las De la Canal en San Miguel de Allende, que parecen sostenes un, florero on una lámpara en las manos. En nuestro tiempo el criterio artístico ha variado $y$. debemos ver-en estas obras no sóbo burdos simulacros de edtatuas sinó creaciones nás ingenuas, más cercanas a la intimidad del espiritu, que no las obras liamadas clásicas que a veces resultan de un amaneramiento tan forzado que sólo las de los genios, las de los escultores de primer orden, parecen aceptables. Dentro del feriómeno que implica no sólo la parte artística del asunto, sino en lo que atañe a las costumbres sociales de los habitantes de la Nueva España, es interesante estudiar esta escultura funeraria. 
Comenzaremos por reseñar aquellas obras de que tenemos noticia documental, pero que ya no existen, para transcribir después la nómina de las que aún se conservan, con los datos que acerca de ellas hemos recogido.

Entre los más antiguos sepulcros de que se conserva noticia en México, deben mencionarse los de la familia Cervantes, que tenía su entierro en la sala "De Profundis" del convento de San Francisco, en tanto que los Condes de Santiago lo tenian en la sacristía. ${ }^{2}$ Los López de Peralta poseían dos sepulcros, uno en la iglesia de Santa Clara y otro muy suntuoso, en la sacristia de San Agustín,' que compró el tesorero Jerónimo López para ese objeto. El hecho de tener sepulcros en las sacristías quizá se deba a la prohibición de los concilios de levantar sepulcros en los templos y es posible que éstos de las sacristías sí tuviesen estatuas.

Martin de Ircio y Juan Jaramillo tenian sus sepulcros en el templo de San Agustín. ${ }^{3}$

En la antigua iglesia de Santo Domingo, construida por segunda vez de 1563 a 1590 , existian muchos sepulcros, aunque no sabemos si estaban decorados con estatuas. Podemos mencionarlos gracias al plano del templo, publicado por don Diego Angulo. ${ }^{4}$ En el presbiterio, al lado del Evangelio, estaba el sepulcro de don Luis de Velasco, el primero, concedido con particular licencia de su Majestad. La capilla del lado de la Epístola, que comunicaba con el presbiterio por un arco de medio punto, pertenecía a don Luis de Castilla. El mismo lo dice en la información que hicierón los dóminicos de México en 1578 para reconstrucción de su iglesia: "Demás que este testigo (don Luis de Castilla) tiene en él su capilla y enterramiento y de su muger . . " La capilla del lado opuesto era de don Diego de Ibarra, conquistador de Zacatecas. En el brazo del crucero del lado de la Epístola estaban los entierros de todos los vizcaínos $y$ montañeses $y$, en el lado opuesto, gran cantidad de sepulcros en el piso: el entierro de Angè de Villafañe sin ninguna señal externa. A la derecha de la puertá, el entierro de Luis Suárez de Peralta, señalado con un arquillo embebido en la pared; a la izquierda del altar, el entierro del Gobernador Estrada con sus armas y, en el muro optesto al altar, el entierro de Manuel de Villegas; señalado con uń arquilio en la pared. Es posible que estos arquillos tuviesen estatuas orantes o por lo menos los escudos de los personajes en ellos sepultados.

2 Rometo de Terrezos, op. cir.. pág. 63.

3 Así conata en an viejo manuscrito que existía en la biblioteca del Museo Nacional y ha detaparecido.

4 Plános de Amfrica y Filipinas Lámina 1 A. Texto páge. 12-14.

5 Ojea. Crónica. Información de los Domínicos. Pág. 36. 
Si recordamos que en el siglo xvIr casi todas las iglesias fueron hechas por personajes de la colonia es de presumirse que en muchas de estas iglesias existieron, por lo menos, estatuas orantes de sus patronos. Las que han llegado a nosotros permiten suponer ese hecho; otras veces, como hace notar el señor Romero de Terreros, se colgaban los retratos, pintados al óleo de los difuntos.

La ciudad de México debe haber sido muy rica en estatuas funerarias pues se sabe de muchos patronos que fueron enterrados en los templos que habian edifieado a su costa. La Encarnación, por ejemplo, tuvo por patrono primero a dọn Sancho Sánchez:de Muñón, el célebre Maestrescuelas de la catedral, y luego al riquísimo Alvaro de Lorenzana que fué sepultado en la iglesia en la bóveda que allí tenía. Doña Catarina de Peralta, viuda de don Agustín de Villanueva Cervantes era patrona del convento de Santa Isabel y es posible que alli haya tenido su sepultura." Del convento de la Piedad se sabe que era patrono Juan Guerrero de Luna ${ }^{8}$, asi de muchos otros. De algunos consta que poseían estatuas como los Retes Largache en el templo de San Bornardo. Lo. refiere así el poeta Alonso Ramirez de Vargas en el curioso libro que publicó con motivo de la dedicación del monumento: "Sagrado Padrón y panegyricos sermones ... en la dedicación del convento religioso del gloriọso A bad San Bernardo" impreso en México en 1690. Dice que se veían las estatuas de los cuatro patronos $y$ dedica un soneto culterano a la del capitán don Joseph de Retes y Largache, principal benefactor del monasterio:

Aquella estatua cuyo peso oprime

- el breve sitio donde se decora, voz eloquiente oculta donde implora nuevo espíritu goza que el anime.

El juicio duda en que la especie imprime, si la lengua pronuncia, el mármol ora. Miran los ojos o el semblante adora: tanto cincel valiente, afecto exprime.

Devota, arrodillada, se refiere a su dueño excediendo de trasunto en quanta alma vivaz informar quiere.

6 Ramirez Aparicio. Conventos Suprimidos en Méxica. Pag. 147.

7 González Obregón. México Viejo.ji, 247.

8 Ojex. pág. 30. 
Mas sacrificio a Dios se halla en un punto: estar gozando alla to que no muere, y acá adorar viviendo lo difunto."

A juzgar por lo qque dice en el segundo verso de la segunda cuarteta las estatuas eran de mármol, dato interesante.

Entre los documentos valiosos que enriquecen nuestro trabajo, merece citarse en primer lugar ef proyecto para una sepultura con estatua crante que reproducimos aquf:'mismo. ${ }^{10}$ "Don Juain de Chavarría nació en México y fué bautizado en el Sagrario. Metropolitano el 4 de junio de 1618. Se caso con dona Luisa de Vivero y Peredo; hija del segundo conde del Valle de Orizaba, don Luis de Vivero y doña Graciana Peredo y Acuña. Reedificó la iglesia de San Lorenzo y en ella se le díó el hábito de Santiago en 26 de diciembre de 1625."11 "Murió en México el 29 de noviembre de 1682 y como a patrono que era de San Lorenzo, sobre su sepulcro se le erigió una estatua de piedra, que lo representaba hincado de rodillas sobre un cojín y en actitud devota." 12

Tales son las noticias históricas que poseemos acerca de este caballero. Si realmente se trata del proyecto para su sepulcro, podemos darnos euerta de cómo fué éste realizado y después corriendo los años, lastimosamentè destruído. Mutstranos el dibujo una estructura de dos cuerpos: el bajo de oriten toscano con su entablamiento cómpleto y colummas pareadas a los lados, más resaltadas las centrales. En el centro un encasamento adintelado que cobifa la estatua orante. El segindo cuerpo descansa en un ático, a los lados del encisämentó se ven las moldirias de un frontón roto y el ático está encasetonado. En los extremos correspondientes a las columnas se levantan perillones piramidales y ai centro se desplanta el segundo cuerpo, con pillastrillas y con adornos imbricados. Al centro, un

9 Existen dos edicionez del mismo libro bechas en el ptopio afo de 1690 , pero en una no figura el sermón de Ramirtz. Mi cotimada discípala la veñorita Josefina Mnriel de la Torre. me comunicó el dato, lo que mucho le agradezco.

10 Agradezco a la señorita Eva Martinez Ceballos la coinnzicación de eata fotografía que le fué proporcionada por el historiador don Franciato Fernandez del Caytillo, quien le aseguró que poowenía del archivo del templo de Sall Lorezzo de Mérieo F era el proyecto para el sepulcro del patrono don Juan de Chavaría.

11 Gonzelez Obreg6n. Múxico Viejo y Anectótico. Pag. 13. Da noticia de 12 toma de hábito de Santiago el "Diario"" de Guijo.

12 Gonźliez Obregón, ibid. 
gran escudo con su lambrequín, pero sin ningún emblema y rematado todo por un entablamiento imperfecto, con frontón curvilíneo, flanqueado por esferas y en medio la clave, en forma de ménsula, característica del siglo xvr. El caballero aparece de rodillas sobre un cojin, armado de modia amadura, con la espeda ceñida y su yelmo al pie ornamentado con un gran penacho de plumas; usa golilla, cabello cortó, bigote y piocha a la moda de Felipe IV. Como se ve, se trata de una obra de arte barroco que, si fué realizada, sirvió de ornato y lujo a la iglesia de San Lorenzo que edificara el noble caballero. (Fig. 1.)

La vieja Puebla de los Angeles debe haber sido opulenta en estatuas, a juzgar por las noticias que han llegado a nosotros y aun por las propias esculturas que alli subsisten. Cerón Zapata menciona algunos patronos de iglesias poblanas, como Juan García Zerezo y Francisco Téllez, dueños de pastorías en la costa, lo eran de San Francisco (p. 56) ; el capitán Alonso González, dueño de Obrage, de Santa Bárbara o San Antonio (p. 57) ; de Santo Domingo lo eran el Deán Francisco Gallegos Osorio y el Regidor Juan de Narváez (p. 57) ; de Sạ Pablo, el capitán Francisco Alberto Balderráị "insigne bienhechor, pues se ve en su iglesia" (p. 58).

Conservamos, además, noticias precisas de tres estatuas: describiendo Veytia la iglesin de la Santísima Trinidad, dice: "Al otro (lado) del Evangelio está el sepulcro del Illma. y Exrmo. Señor 'Dn. Diego Osorio, que falleció el mismo, año de 1673 , antes de dedicarse la iglesia, y así se depositó su cadáver en su. Santa. Iglesia Catedral y después, en cumplimiento de su diøposición, se transiadó a este sepulcro, sobre el cual está su efigie de piedra, puesta de rodillas, y delante las inscripciones que declaran su nombre $y$ dignidades $y$. la erección que hizo de esta iglesia, y en el coro, en ự nicho de la pared, está su corazón."."

El Colegio de San Ildefonso fué fundado por el ilustrisino señor don Alonso de la Moth y. Escotar y an iglesia; cuyo interior ofrece un bello ejemplar del arte barroco potblano, se le hizo st sepulcro con estatua otarte. Asi to nefieren les cronistas: Gerón Zapata (pág. 65) dice: "La iglesia e muy capaz y bien adornada de lucidos colaterales; y al lado del Evangello está en un curioso nicho la efigie de su Patrón perinanieciendo hasta

13 Historia de la fundación de la ciudad de Puebla de los Angeles en la Nueva Enpaña. Su descripción y presente estado. Su nubor: el licemciado don Matiano Fernández de Echeverria y Veytia. 2 vols. Puebla, 1931, 4, 520. 
ahora (1689 ?) los paños de corte que fueron de dicho señor." Llanraban paños de corte, en la época colonial, a las tapicerías.

Veytia se expresa en los siguientes tếrminos: "Se depositó su cađáver en la santa iglesia y después se trasladó a la de su Colegio de San Ildefonso, donde descanșa al lado del Evangelio, por haberio así ordenado en su última disposición; sobre el sepulcro se colocó su efigie de piedra puesta de rodillas y en la lápida que la cierra se lee esta inscripción:

Illmus. D. D. Alphonsus de la Mota et Escobar, Episcopus Tlaxcalensis, Fundator huiua insignis Collegii. Mota est, nam moritu, sed mens immota manebit, Dum jacent hic corpus, vivit, at ipsa Deo,"

EI señor Mota falleció el 16 de marzo de 1625 después de gọernar su diócesis diez y nueve años y en su retrato se colocó esté elogio:

$$
\text { Pacificus, Eloquens, Magnificus. }{ }^{14}
$$

El mismo historiator Veytia, tan detallado y miritucioso, nos da noticia de otra estatua que existía en el templo de las Capuchinas. Hablando de la iglesiá, dice: "La consagró el Ilmo. Señor Dr. Miguel Anselmo de Abreui y Valdés; auxiliar de este Obispado el día 27 de septiembre del año de 1761, asignando el mismo día para rezo de su dedicación. El día $1{ }^{\circ}$ de diciembre del afto de 1711 se transladaron a esta iglesia los huesós de los fundadores, los de Dn. Diego Lagarche al presbiterio al lado del Evangelio donde se puso su estatua de piedra y encima su escudo de armas y los de la Señora dofa Ana en el coro bajo; en el sepulcro de las teligiosas." 10

Menciona el señor Romero de Terreros algunas esculturas que ya no existen : las estaturas de los condes del Valle de Orizaba se éncóntraban en la gran iglesia franciscana de Tecamaclialco, pero en la actualidad han desaparecido. La de don fray Antonio Alcalde, el famoso fraile de la Calavera, se veía en el Santuario de Guadalupe en Guadalajara. Parece que ésta ha pasado hoy al museo instalado en el antiguo seminario.

En el templo del Carmen, de San Luis Potosi, existió la estatua funeraria de su fundador, don Nicolás Fernando de Torres, mandada, erigir sobre sid tumba el 29 de diciembre de 1784 por el prior fray. Juan de Jesús María y José, el cual "mandó abrir en la pared del presbiterio, al lado

14: Veytia, op. cit., II. pig. 194.

15 Veytiz. op. cit., if, pkg. 540. 


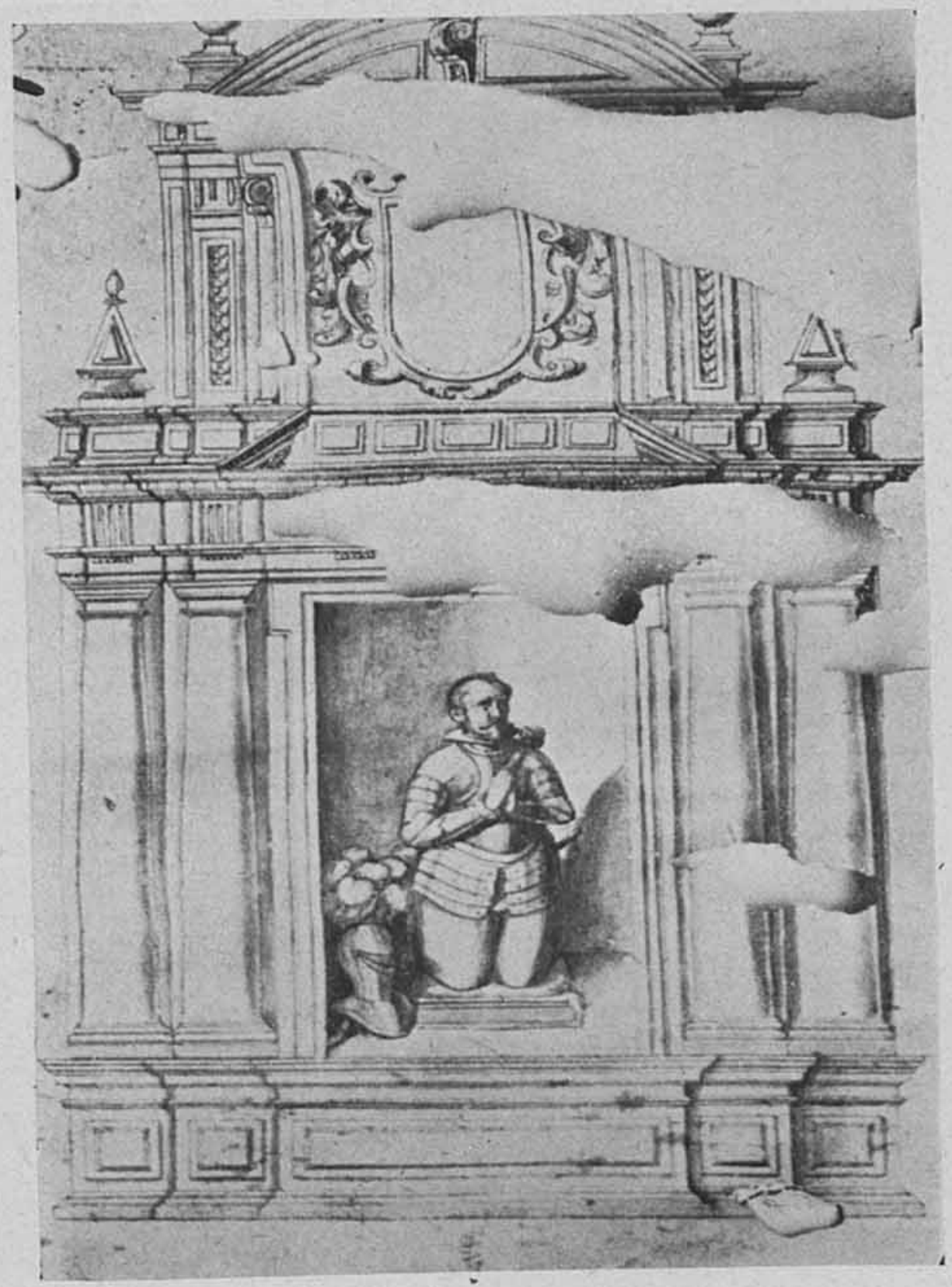

1. Proyecto para el sepulcro de don Juan de Chavarría. Iglesia de San Lorenzo. México. 


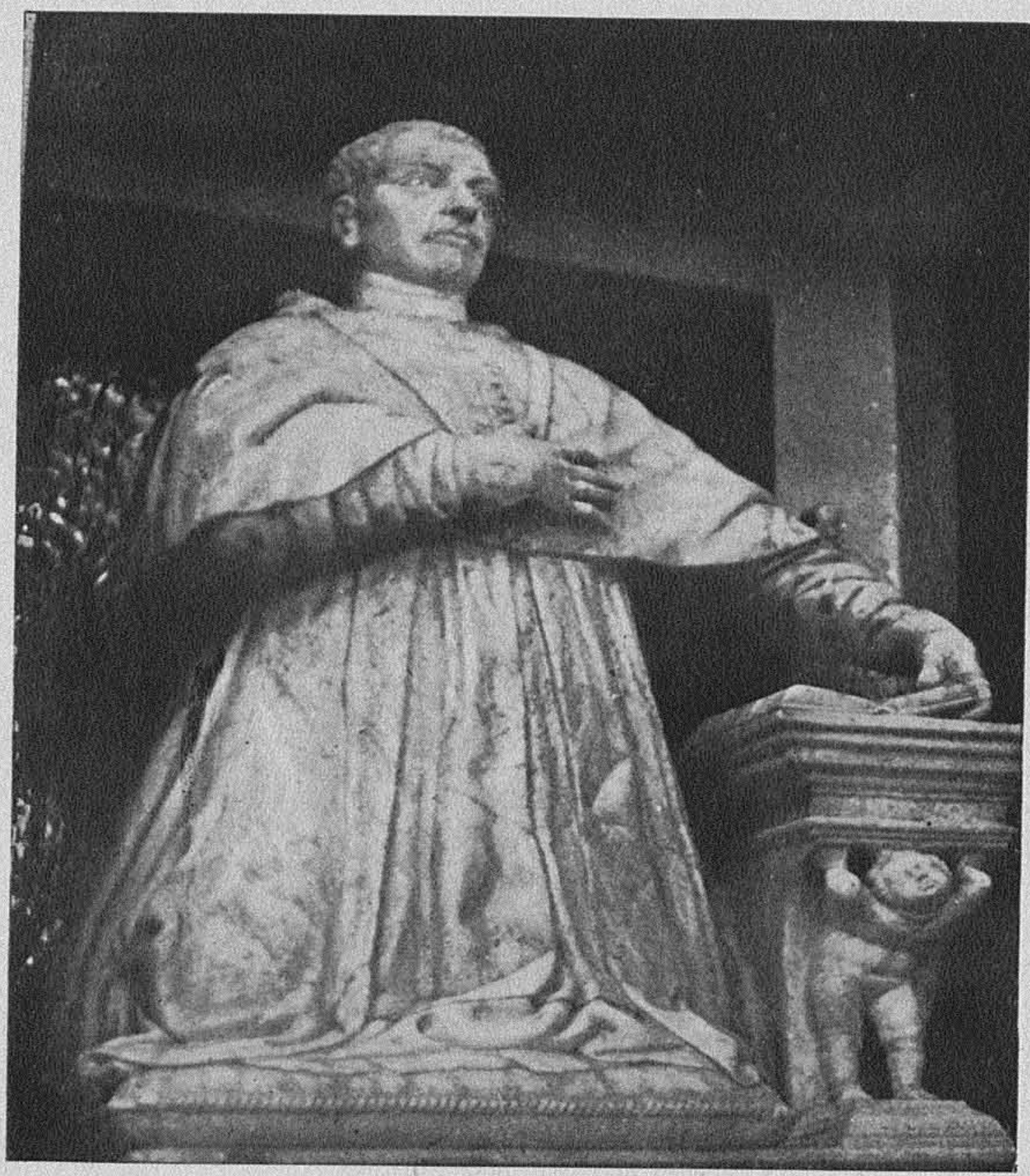

2. El obispo don Manuel Fernández de Santa Cruz. Iglesia de Santa Mónica. Puebla. 


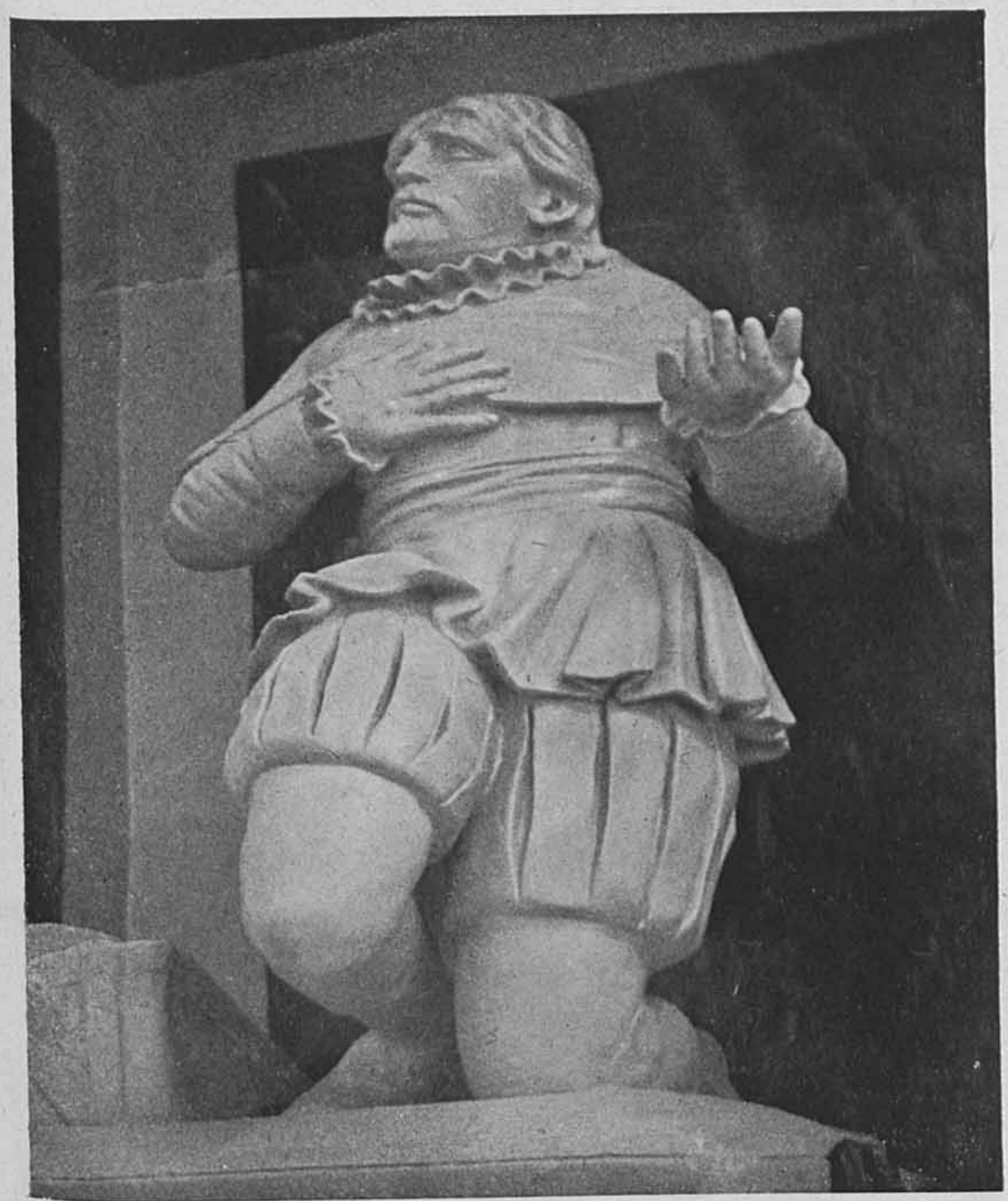

3. El Capitán don Jorge Cerón Zapata. Iglesia de Santa Mónica. Puebla. 


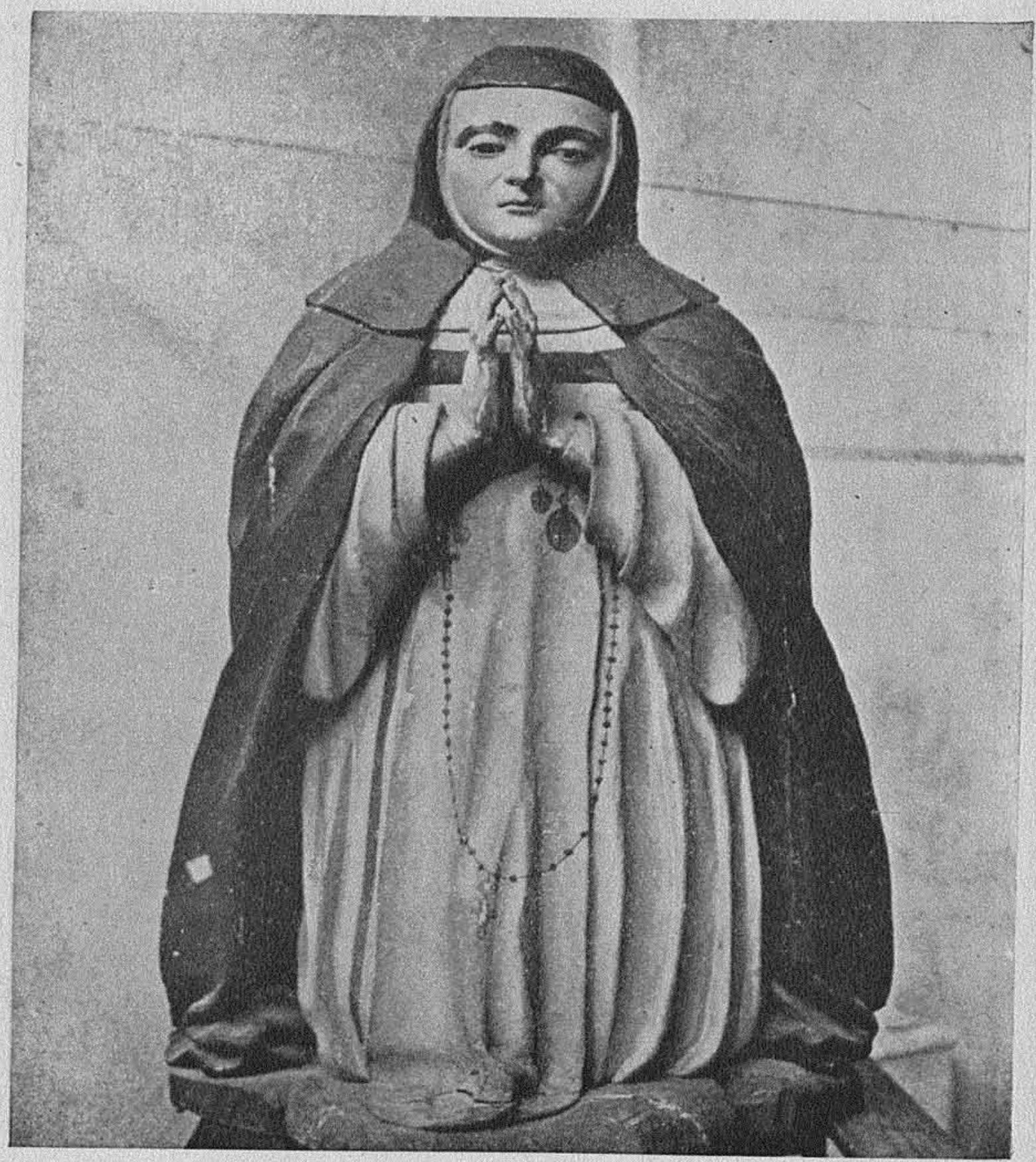

4. Sot Maria ce la Cruz. Museo de Santa Mónica. Puebla 
DOI: http://dx.doi.org/10.22201/iie.18703062e.1944.11.372

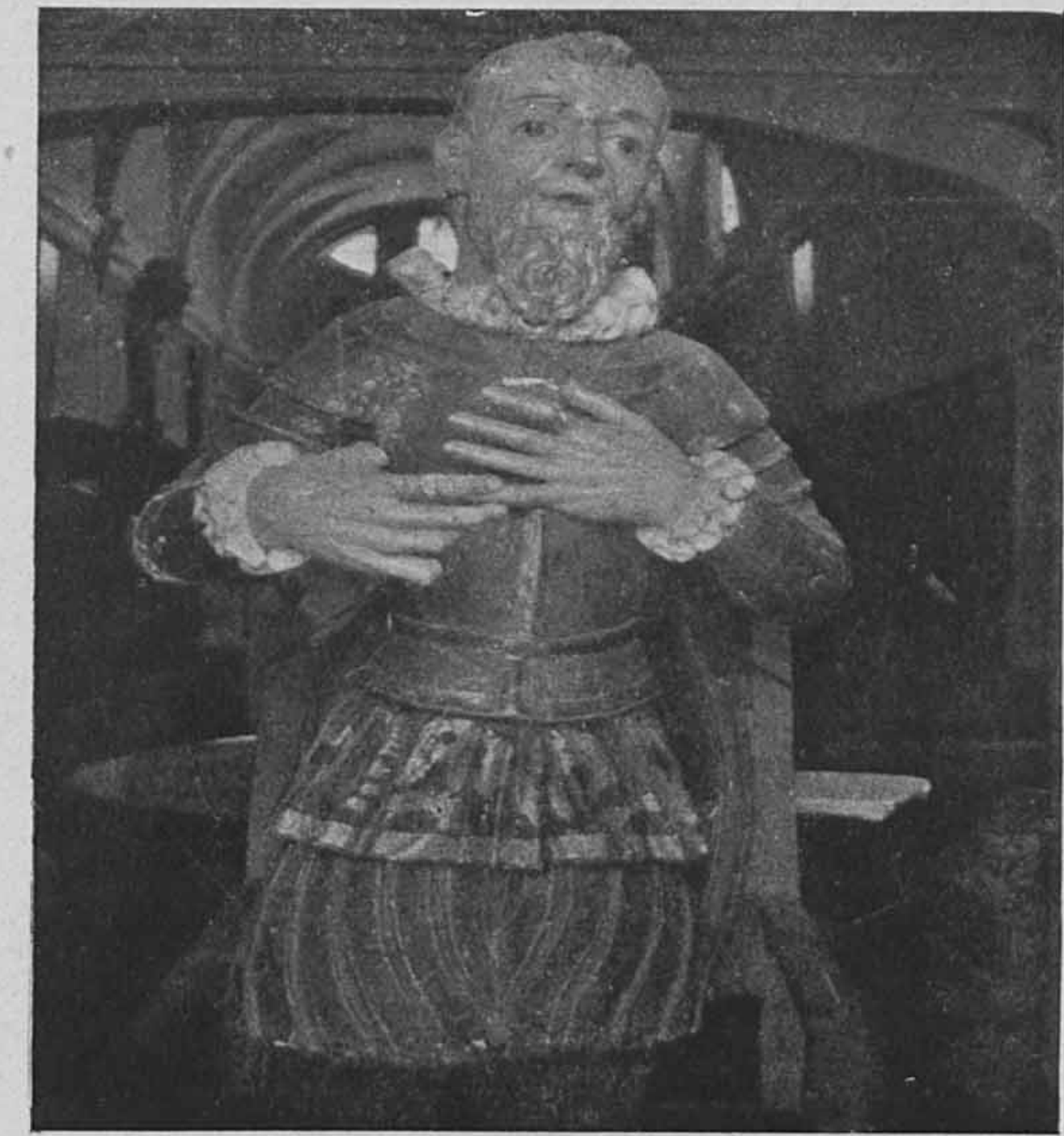

5. Don Melchor de Covarrubias. Existia en el Colegio del Estado. Puebla. 


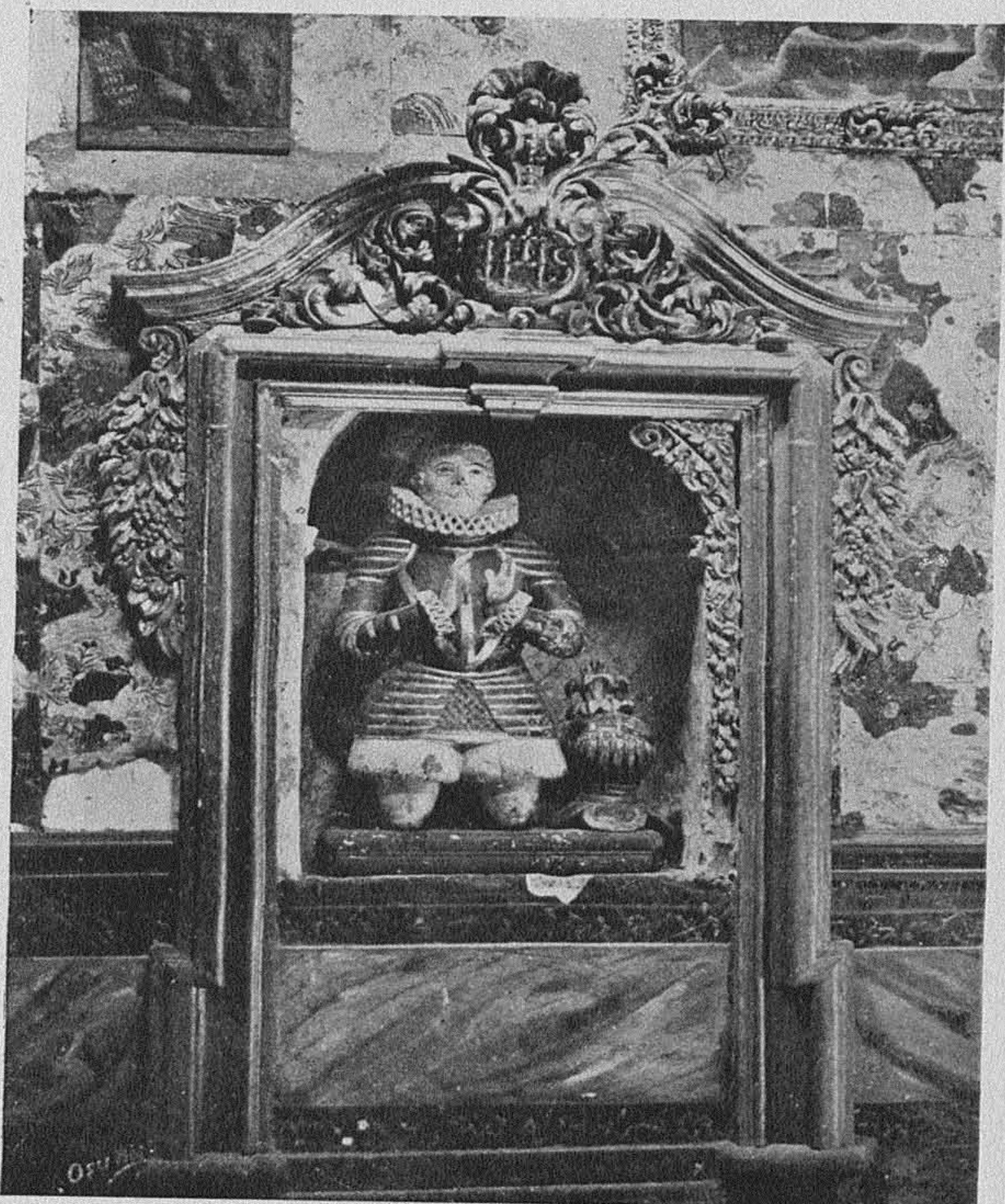

6. Don Pedro Ruiz de Ahumada. Capilla de los novicios del Colegio de Tepozotlán, Edo. de México. 
DOI: http://dx.doi.org/10.22201/iie.18703062e.1944.11.372

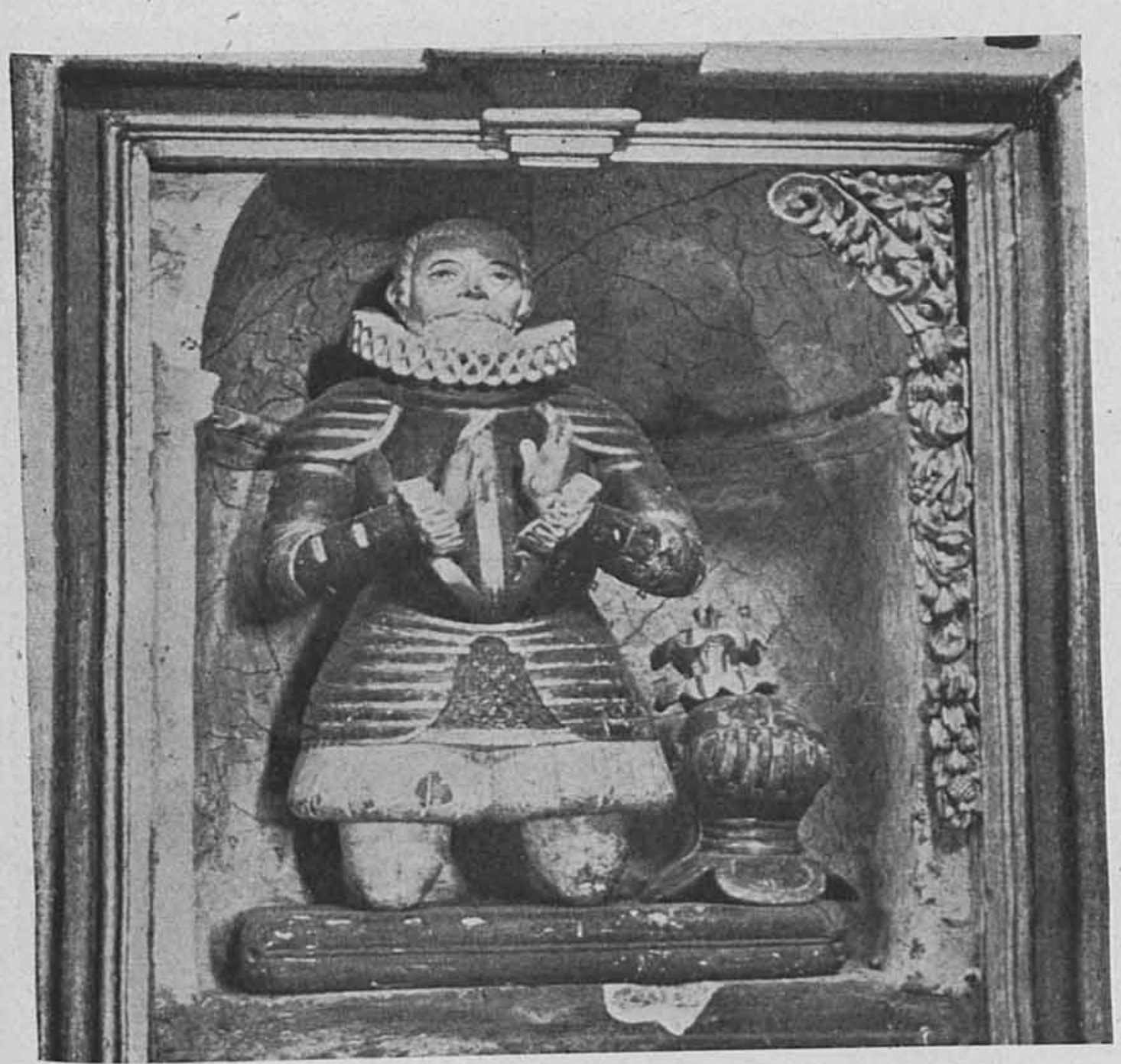

7. Detalle del anterior. 
DOI: http://dx.doi.org/10.22201/iie.18703062e.1944.11.372

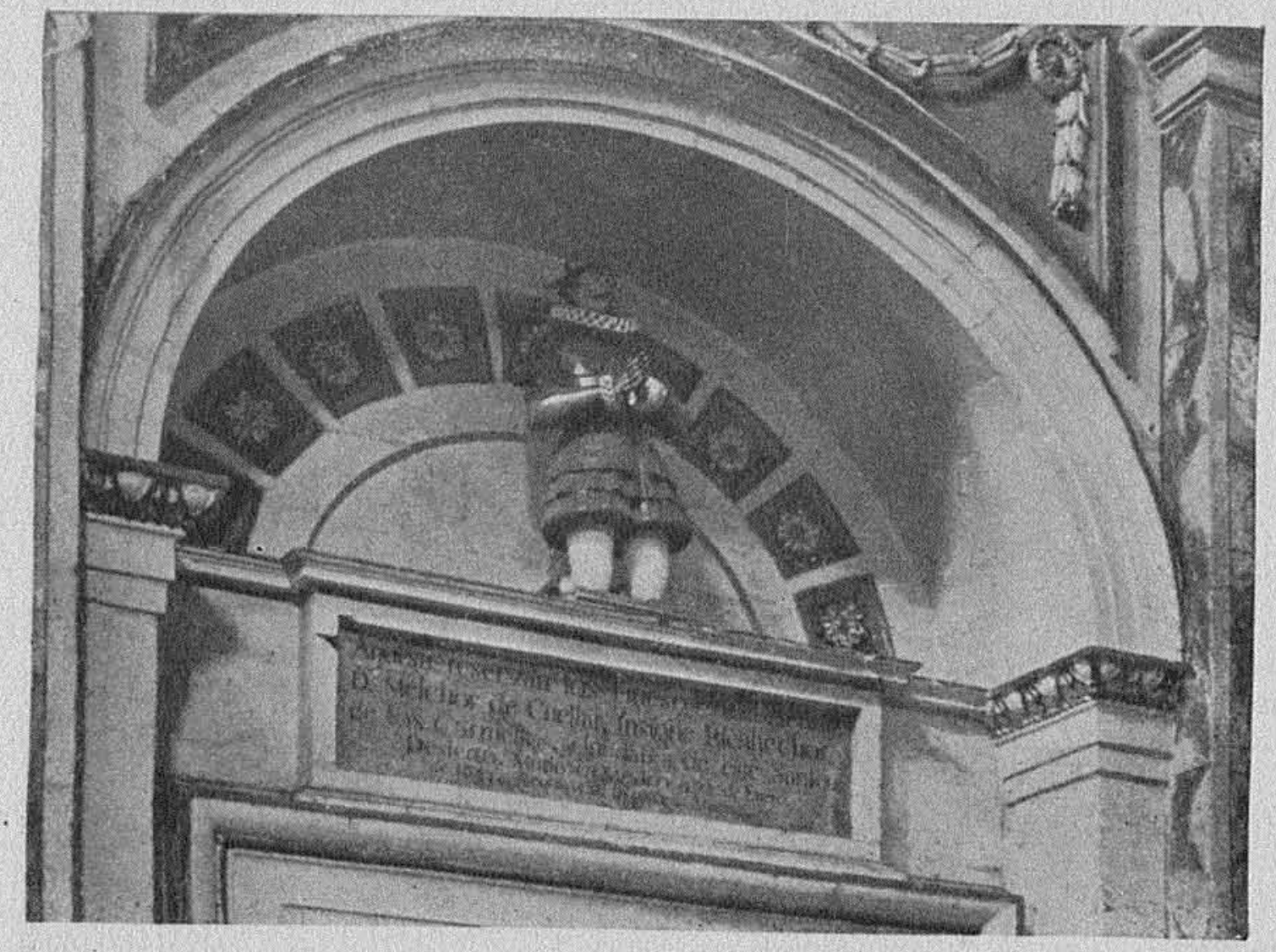

8. Don Melchor de Cuéllar, Iglesia del Carmen. Tenancingo, Edo. de México. 
DOI: http://dx.doi.org/10.22201/iie.18703062e.1944.11.372

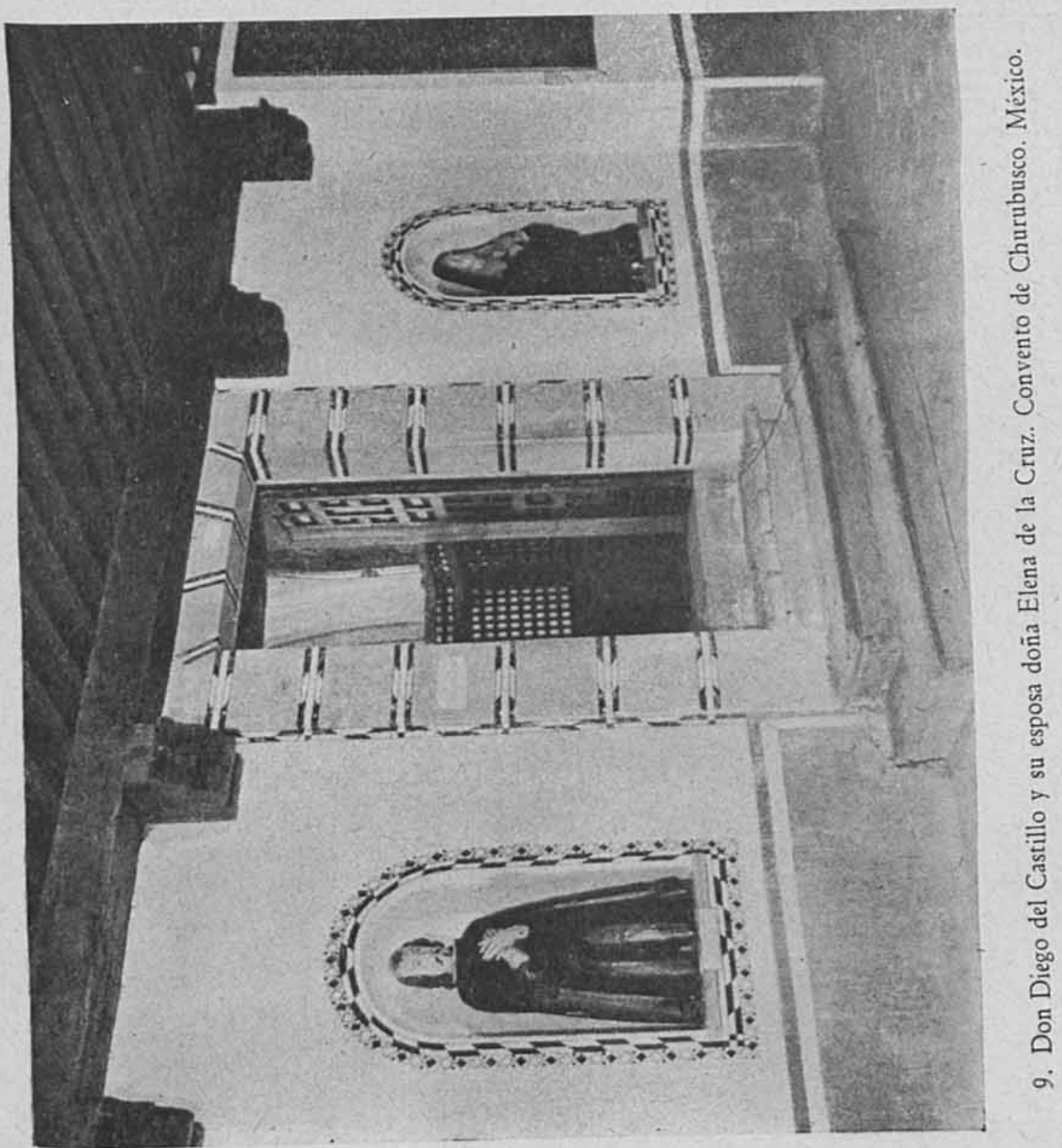




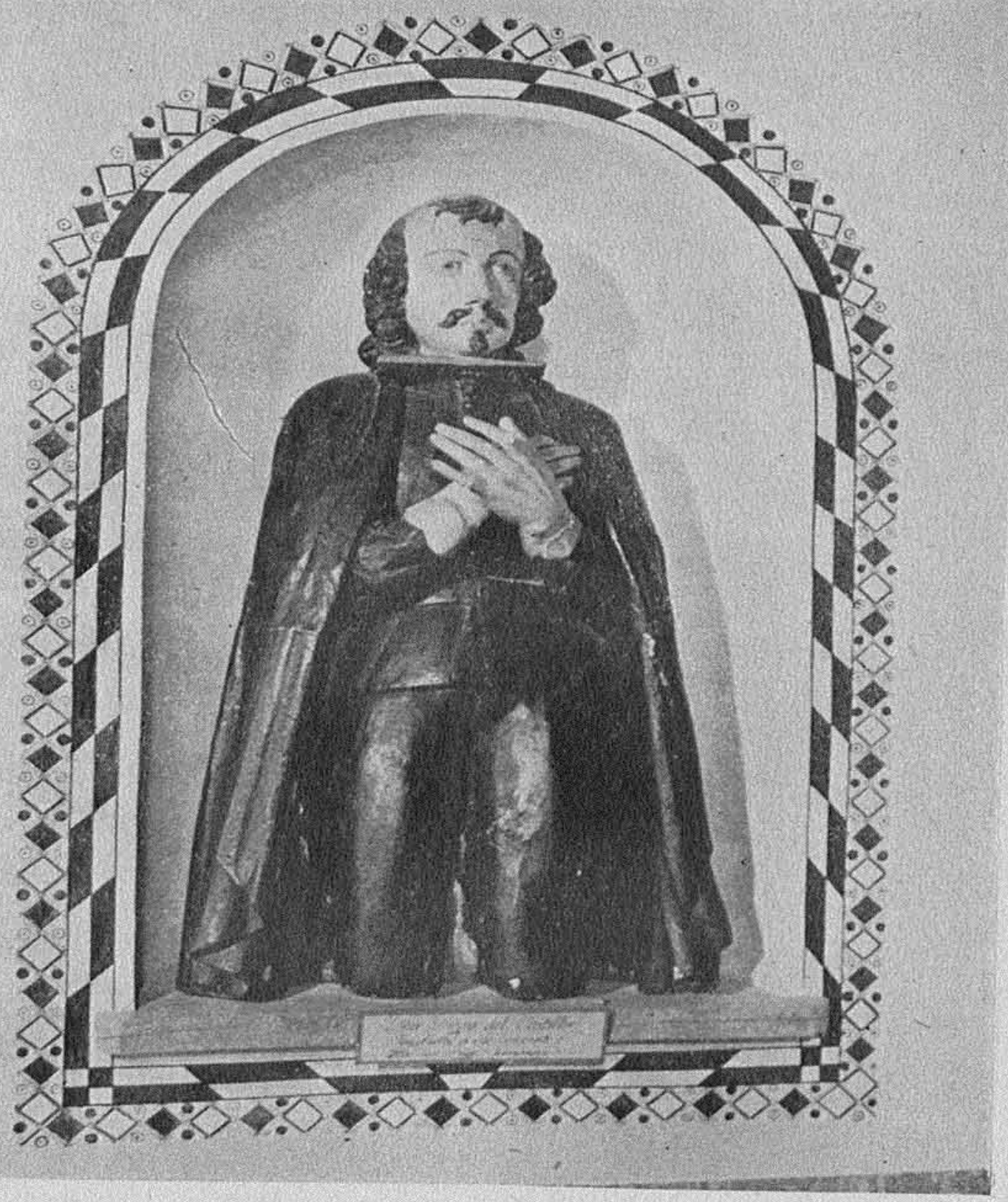

10. Don Diego del Castillo. Churubusco. 


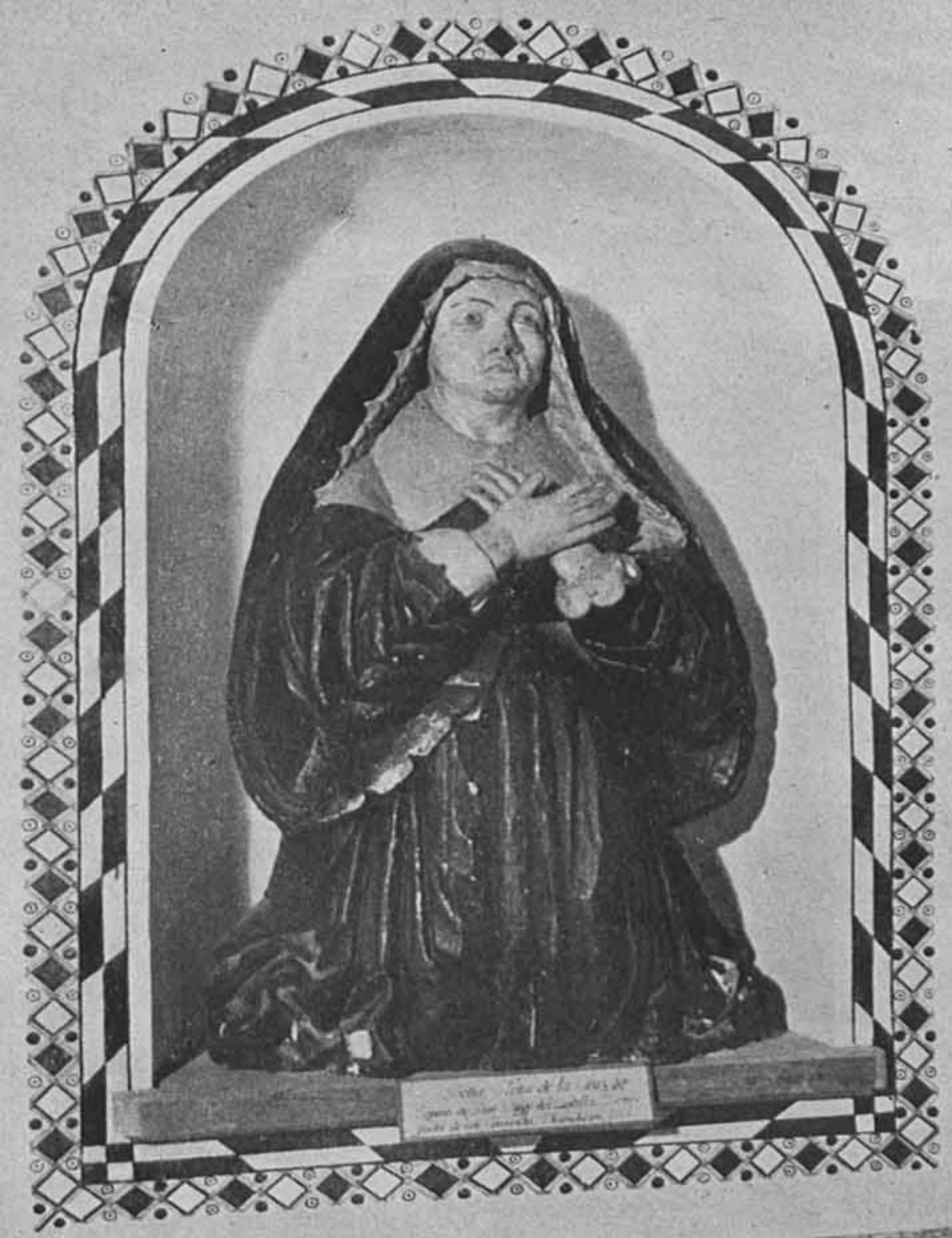

geresusen

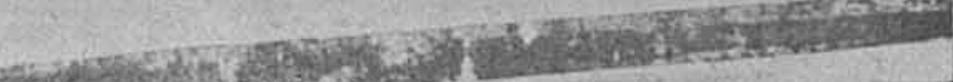

11. Doña Elena de la Cruz. Churubusco. 


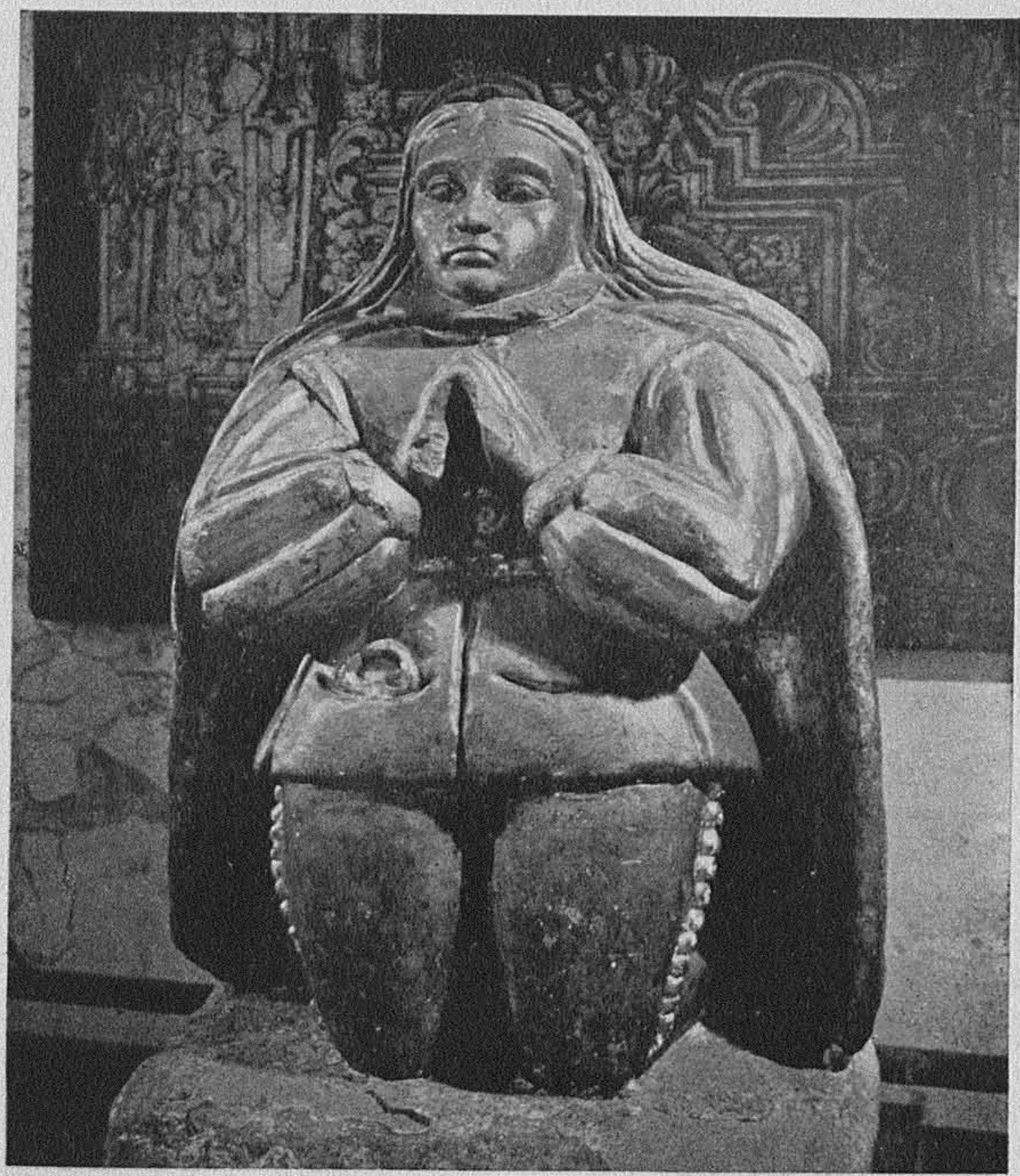

12. Don Diego Juárez de Peredo o don Diego de Agreda. Convento de Churubusco. 


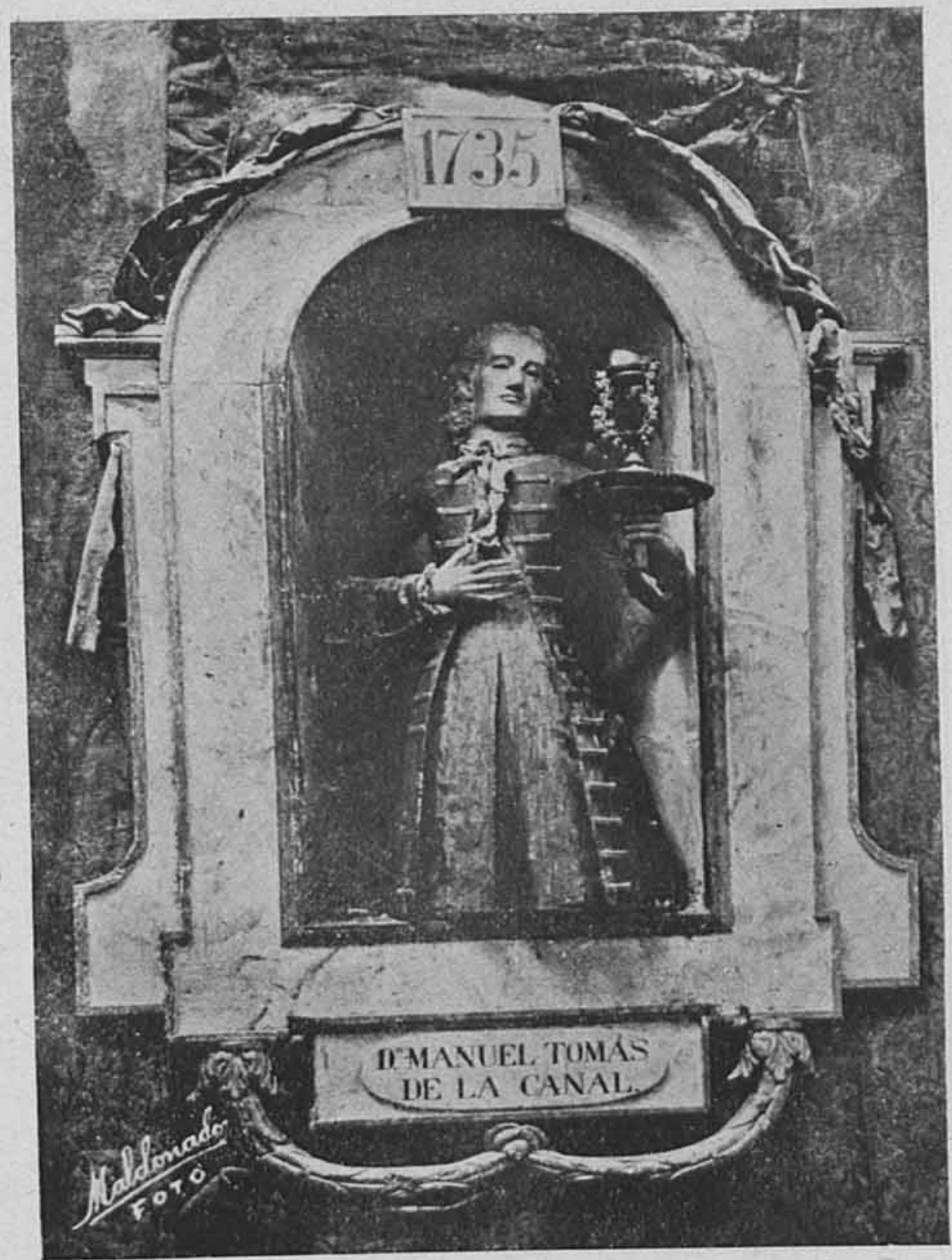

13. Don Manuel de la Canal. Capilla de Loreto en el oratorio de San Felipe Neri. San Miguel de Allende. Gto. 


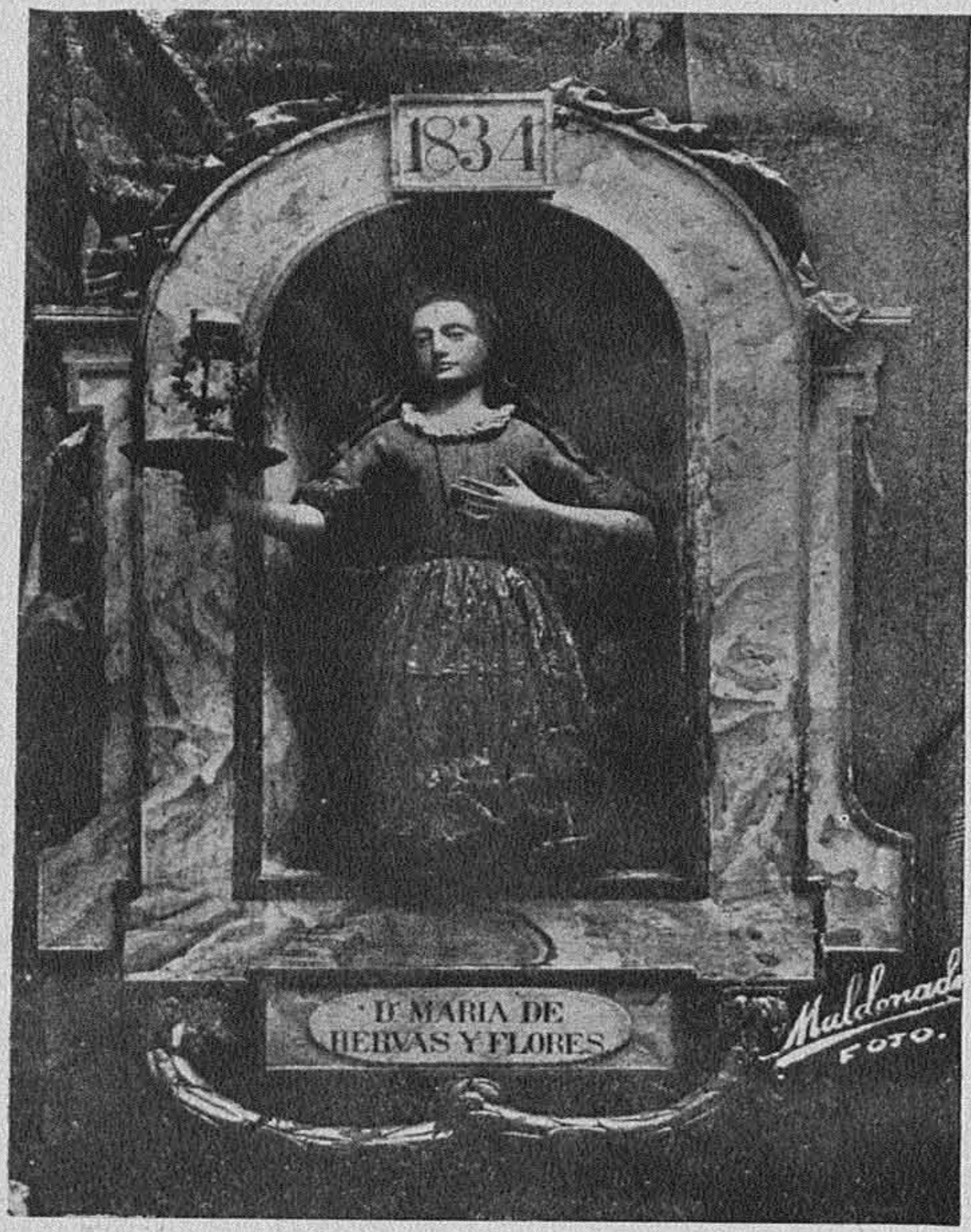

14. Doña María de Hervas y Flores. Capilla de Loreto en el oratorio ce San Felipe Neri. San Miguel Allende, Gto. 


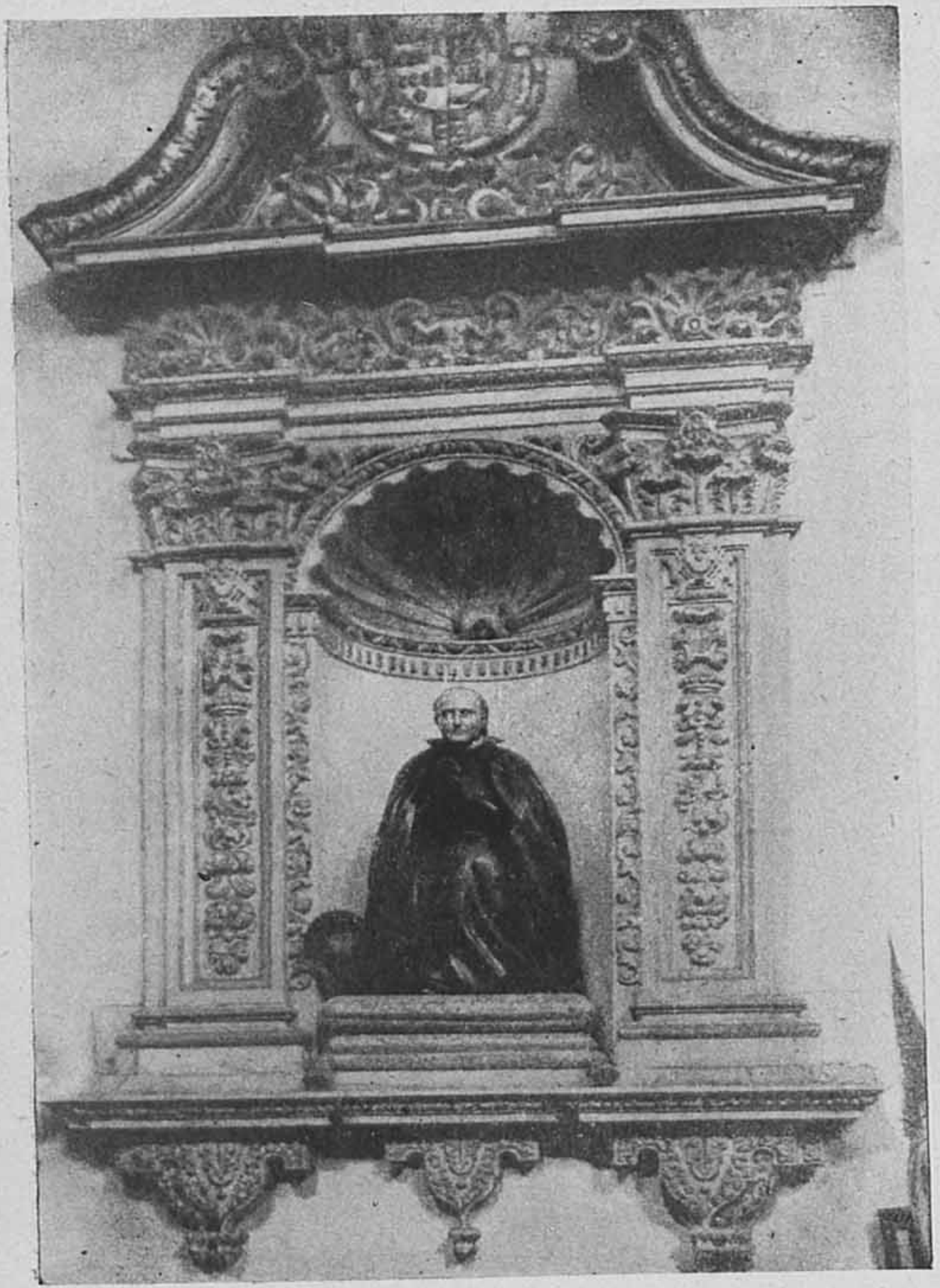

15. Don Buenaventura Medina Picazo.

Capilla de la iglesia de Regina. México. 


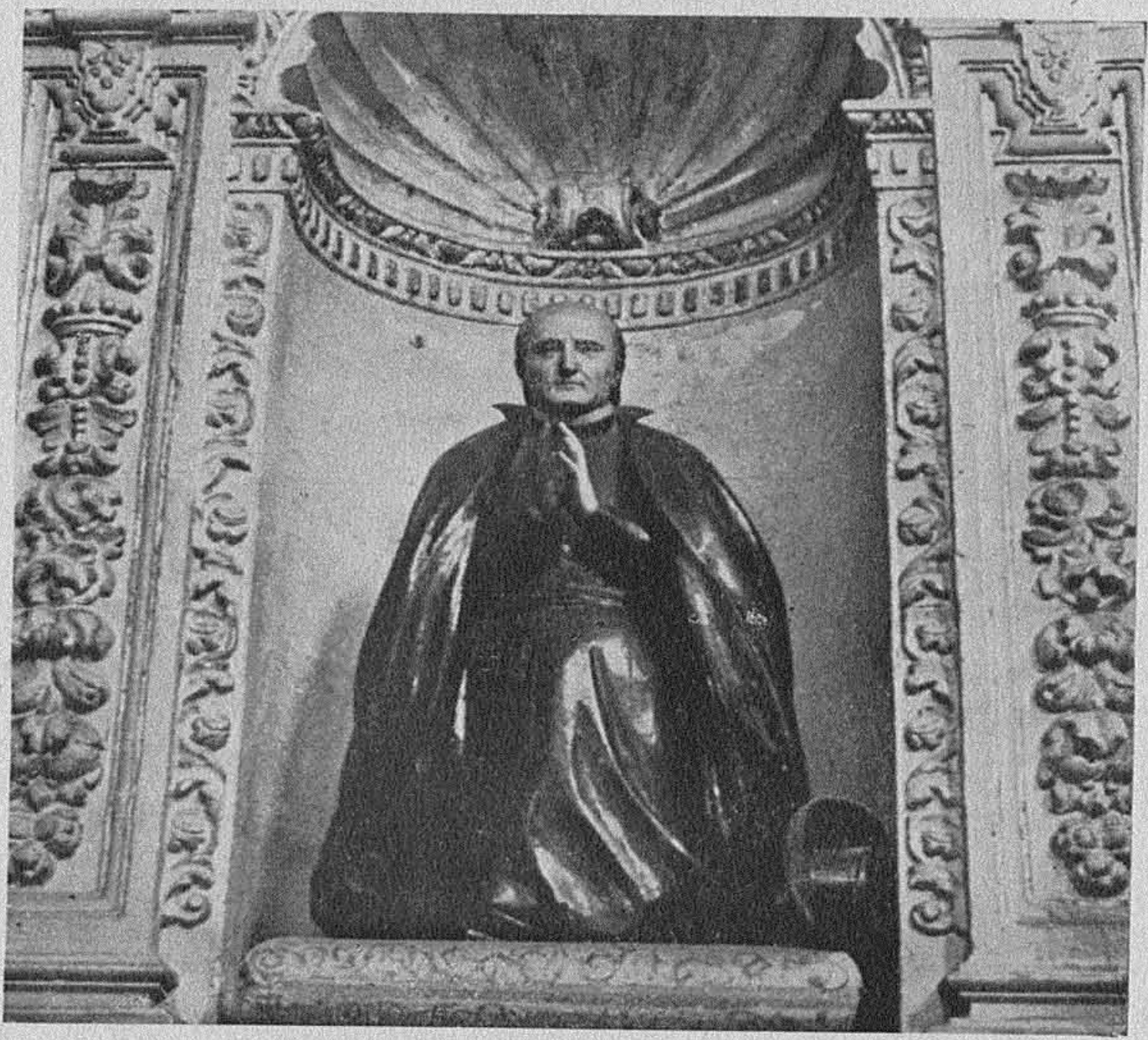

16. Detalle del anterior. 
DOI: http://dx.doi.org/10.22201/iie.18703062e.1944.11.372

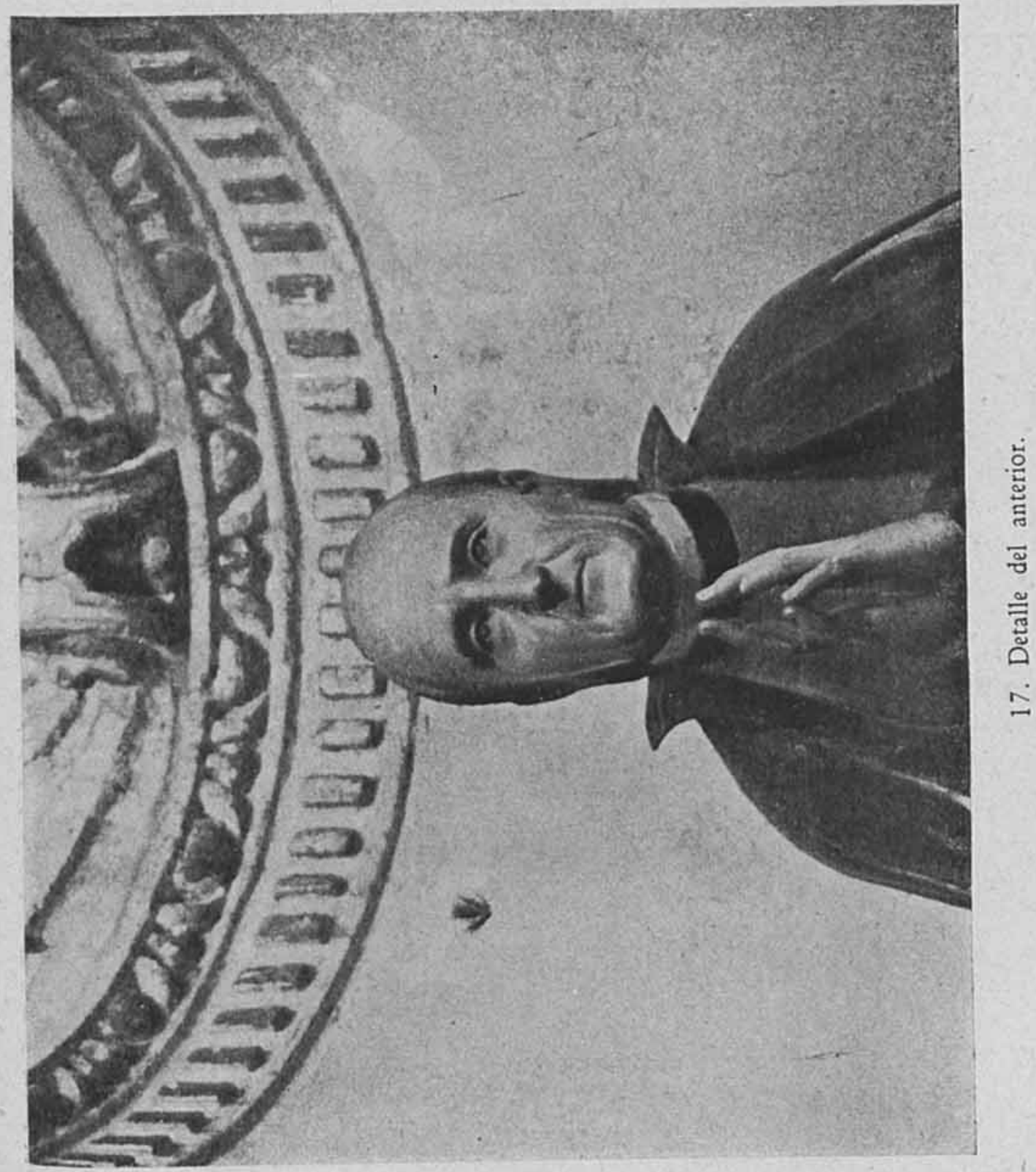




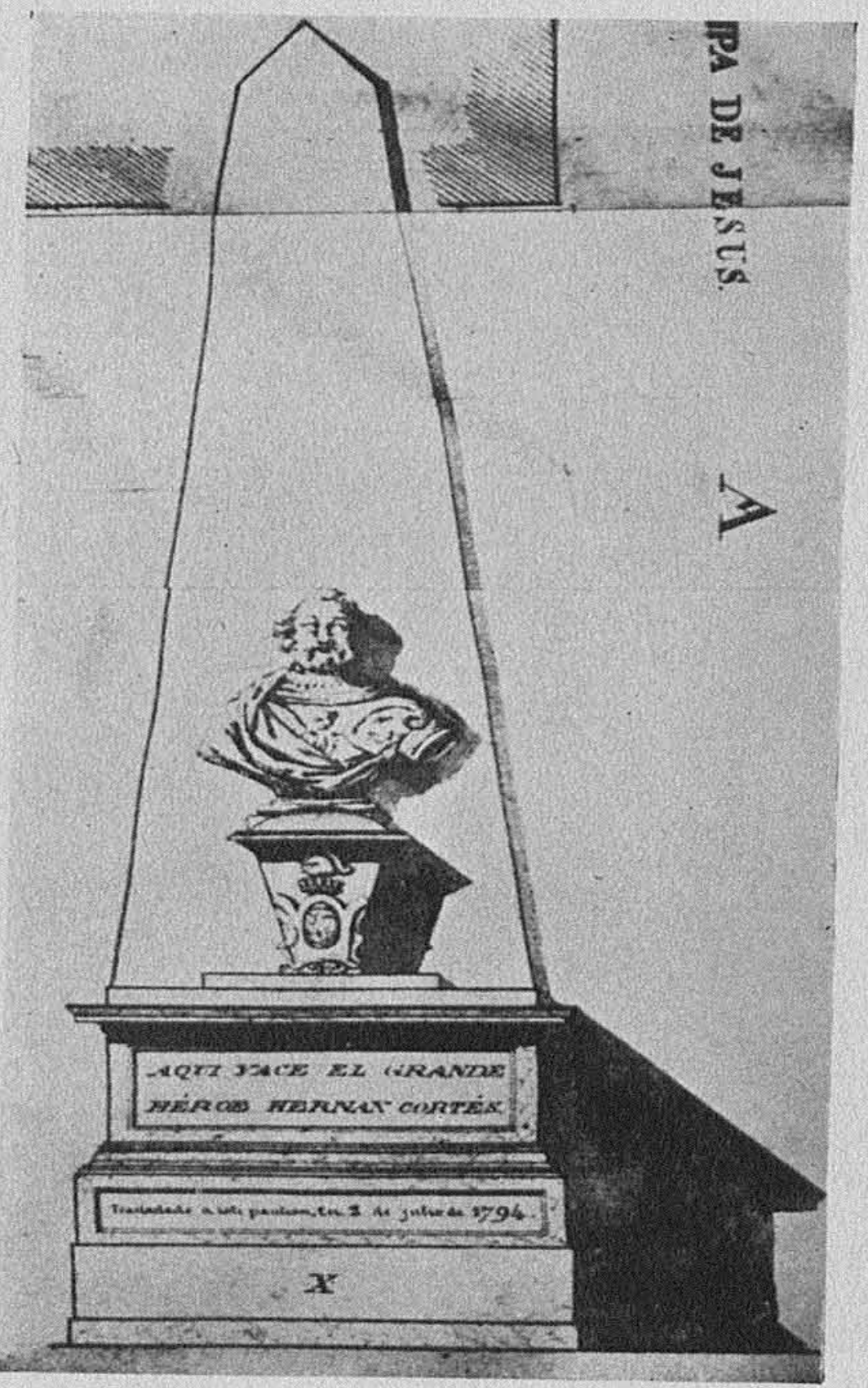

18. Sepulcro de Hernăn Cortés que existia en sel templo del Hospital de Jesús. México. 
del Evangelio, dos varas elevado del pavimento, al pie de una repisa de piedra sobre cuya planicie en un fingido cojín estriba de rodillas una es. tatua de nuestro fundador, mandada hacer y puesta alli por fray Juan de Jesús Maria y José... "16

Actualmente se conserva el epitafio latino, ordenado por fray José de Santo Domingo y en sustitución de la estatua una pintura que representa al fundador y a su esposa doña Gertrudis Maldonado Zapata.

En Zacatecas, en la iglesia de la Compañia, que fué edificada del 14 de febrero de 1746 al 19 de abril de 1749 , existían las estatuas de los füdadores: “... eternizadas en Estatua las memorias del Sr. Maestre de Campo D. Vicente Saldivar, Fundador de este Colegio, juntamente con la de su Nobilisșima Consorte Dofia Anna Bañuelos, nuevamente retratada enfrente de su Esposo por haber sido la primera Authora de la Funtación." 17

Hablemos ahora de las estatuas que aún póseemos. La ciudad de Puebla es la más rica en esculturas funerarias, así como en noticias de las que existieron, como hemos visto.

La más notmble escultura de esta indole que se conserva es la del señor obispo don Manuel Fernández de Santa Cruz, que existe en la iglesia de Santa Mónica, en un encasamento al lado del Evangelio. (Fig. 2.) Es de mármol, bastante bien trabajada, data seguramente del siglo Xvir. Viste el. obispo su gran manto episcopal; sus manos están calzadas con guantes; Ih derecha se apoya en el pecho, en tanto que la.izquierda abre un libro que está sobre un reclinatorio, o mesilla, sostenida por un niño desnudo; el prelado está de rodillas sobre un grueso almohadọ́n, El epitafio de la estatua dice asi :

El señor Santa Cruz murió ẹn 1699 , de manera que es posible que su estatua fuese hecha poco tiempo después. Su estilo coincide con el ba-

"El Exmo. e Ilmo. Principe Sot. Dr. D. Mal: Ferz. de Santz Cruz. de las Vírgenes de San Agustín Moderador y Padre. Aqui calla, pero sus piadosas y muy agradecidas hijas, por sí y por la Ciudad de los Angeles, hablan con este monumento; 10 de. octubre de 1841."

16 Crónice de fray Joaḱ de Santo Domingo, en Colección de Documentos para Ia Historia de San Luis Potosi. por Primo Feliciano Velízquez, S, L. P., 1908. Tomo 11. pág. 295. (Dato comunicado por Francisco de Ia Maza.)

17. Breve descripción de la fabrica $\dot{y}$ adornos del templo de la Compañía de Jetis de Zacatecas: los seis ilustres caballeros de la dedicación. México, 1750. 
rocer de la época que 1tegé hasta los primteros antes del siglo xurt. Es de notar que el ameglo actual de ta estatria chata de lis41; peró en st tiempo ef nicho correspondia af estilo barroco extaberatite de la época, como fifce Cerón Zapata: "En donde al lado del Evangelio, muy bien compuesto de follzjes dorados, se puso la efigie del Ilmo. y Rmo. seffor Don Manuel Fernández de Santa Cruz : . "ro

Frente a la estatua det señor obispo se ve la del benefactor de la iglesia, el capitán đon Jorge Cerôn Zapata. (Fig. 3.) Parece que fué colocada al mismo tiempo que la del obispo Santa Cruz, por más que su indumen taria no corresponda a la époça en que el caballero murio, sino a una anterior, del siglo $x v i$ pero no más. La estatua no es de mármol. Se encuentura en una actitud movida, no de legítima estatua orante, sino como en la actitud de levantarse del almohadón en que aún conserva hincada la rodiIla izquierda; la mano derecha al pecho y la izquierda coma si sostuviera algo. El nicho era semejante al del señor Obispo Santa Cruz, como lo rofiere Cerón Zapata. Por su actitud de movimiento y los amplios pliegues que ostentan sus paños, esta cotatua resulta muy agradabli:

En el museo do Santa Mónica existe la estutua orante de una monja, en madera policromada, del habito de Santo Domingo, con su rosario y medallas colgando Reoresenta sor Maxia de la Cruz. (Fig: 4). Priora de algún é̉nvento de sut Ordén en Puebla. Llamóse en el siglo doña María Móntenegro y se cas 6 con don Francisco Márquez, habiendo ingresado en religión cuando quedó viuda, Es admirable esta escultura por la unción que revela $y$ el sentido popular de sus pafios que cuelgan con toda náturalidad. Las manos han sufrido deterioro y se encuentran como si hubiesen padecido ura terrible: lepra que dejase manchada horriblemente' su piel. ${ }^{10}$

E1 Colégio del Espíritu Santo de Puebla, conocida más tarde por "Colegio del Estado" y después como Universidad de Puebla, fué fundado

18 Cerón Zapata. Pag. 62.

19. Me comunicó la noticia y me propoxeionó la fatografia de enta esatua el ceñor Medel; lo que le agradezco sincerameate; 
por ton Melchor de Covarnubias, hwcia 1578 y a la muerte del caballeso, ccurrida en 1592 , se conservó su retrało de bulto en el templo, como dice Veytia: "Debajo de la tribuna dol lado dẹl Evangelio estŕ colocada la efjgie de piedra del ilustre caballero Melchor de Covarrubias, fundador de este Colegio." 20

Unico recuerdo del sepulcro de don Melchar de Covarrubias en este edificio es una lápida de mármol que se encuentra incrustada en la antesacristía, junto a la de la famosa Catarina de San Juan, "la China Poblana". El epitafio dice:

"Hic jacent cineres, vivit vero memoria perillustris equitis

D. D. Melchioris de Cubarrubias, huius ecclesiae et collegii fundatoris insignis."

Es indudable que la estatua de piedra desapareció con el tiempo, como tantas otras que hemos visto eu la misma ciudad. En la sacristía del mismo templo se conservaba una estatua de Covarrubias hecha en madera policromada; fué retirada de ese sitio y se ie trásiadó al Salón de Actos del Colegio del Estado, mas, como no cabia en el nicho preparado, se le cortó la parte inferior de las piernas, de manera que de una estatua pedestro se hizo algo que no es ni orante ni nada. (Fit. 5.) Más tarde fué retiradi de allí y arrumbada en una bodega. Por eierto, existe el detalle curioso de que las autoridades del Estado'y del Colegio, deseando honrar la memoria del fundador, mandaron hacer una copia de esta estatua en bronce, a tamaño menor que el original, la cual fué colocada en la placeta que queda frente al templo y colegio. Sea por mala técnica, o más bien por la impropiedad de reproducir en bronce algo que fué hecho en madera, la astatua resultó tan ridfcula que fué retirada del sitio poco tiempo después.

Aparece el caballero en pie, vistiendo calzas enteras, gregüescos $\mathbf{J}$ media armadura, bajo la cuad sale el faldellín de una ropilla. Usa cuello corto, encarrujado, así como los puños, baxba cerrada y escaso cabello a las lados y un mechón sobre la frente. Aunque no sea una obra de arte de primera categoría, es indudajte que el escultor reproduce las formas yistas, dentro de gran verismo y es léstima que no se haya sabido conseryar esta estatua aunque sólo fuese a título de curiosidad.

En el Colegio Seminario de San Martin que fundaron los padres jesuitas en el pueblo de Tepotzotlán puede verse, en la llamada Capilla Do.

20 Veytiz. Historia de Puebla. II. 412. 
méstica del piso alto, la efigie, en madera estofada, del protector don Pedro Ruiz de Ahumada (Figs. 6 y 7). Es estatua orante y el nicho que la cobija está lleno de adornos, al parecer del siglo xvir, fecha que corresponde a la escultura, según su indumentaria : está revestido de coraza, tusa gorguera de encaje y puños semejantes. En la abertura delantera de la coraza se asoma una cota de mallas y sus grandes grégūescos acuchilladós le dan a medio musio, que cubre con calzas enteras. Esta de rodillas sobre un cojin y en el mismo descansa un gran yelmo con su penacho de plumas. Es de sentirse que se haya borrado la inscripción o epitafio que debió haber tenido; pero, si tenemos en cuenta que su principal donativo a Tepotzotlán tuvo lugar en 1606 y dada la época en que se usó la gorguera de encajes de gran tamaño, puede asegurarse que esta estatua es anterior a 1620 , en que comienza el uso de la golitia.

Gran vigor ostenta la esculturá ; el verismo del rostro pálido, con cabellera y barba blancas, indica a un hombre entrado en años, pero que aun siente impetus guerreros o que, por lo menos, desea conservar y lucir el prestigio que adquiriera por las armas. Viene a ser, pues, un resto del espíritu caballeresco el que anima a esta escultura. Lástima es que el deterioro del tiempo y la incuria de los hombres destruyan poco a poco nuestras obras de arte, como puede verse en los menoscabos que ha sufrido esta escultura.

En el templo del sagrado Desierto de Tenancingo, fundado por frailes carmelitas, después del pleito que perdieron sobre sus derechos del llamado Desierto de los Leones, se conserva la efigic orante del fundador, don Melchor de Cuéllar (Fig. 8), que los frailes quisieron llevarse consigo a su nuevo ermitorio: "Con 'presea de tal suerte valiosa trasladaron los carmelitas, del antiguo retiro de Santa $F e$, a este de Tenancingo, las cenizas (sic) de su venerado e inolvidable protector, el rico Melchor de Cuéllar, a cuyas dádivas debieron la fundación del primer monasterio. Los restos hállanse depositados en una capilla lateral situada a mano izquierda del altar mayor, en la iglesia; y sobre la cornisa de la puerta de la capilla, en actitud orante, vése la estatua de madera estofada del mecenas, ricamente vestido, con gola encarrujada al cuello y valiosos adornos en el atavío. Hállase de rodillas, como decimos, y mira en actitud de imploración a la imagen de Nuestra Señora del Carmen. 
Sobre la pared, en caracteres rojos y negros léese esta inscripción :
"Aqui se reservan los huesos del Sefror
D. Melchor de Cuellar, insigne bienechor
de los Carmelitas, y Fundador de este Santo
Desierto. Murió en México a 23 de enero de 1633.
Requiescat in pace. Amen." 21

La descripción del señọ Palacios es imperfecta. La indumentaria del caballero es la siguiente: usa coraza, gorguera de encaje y puños iguales. Bajo la coraza cae una especie de faldellín o ropilla que cubre los grandes gregïescos acuchillados que le llegan a medio muslo. Lleva calzas blancas y alcanzan a distinguirse unas botas, atrás; usa el cabello corto, bigote y gran piocha. Como se encuentra a considerable altura su aspecto es un tanto ridiculo, pues su indumentaria parece femenina. Además, se ve una gruesa alcayata de la cual está suspendida la figura. El rostro parece tratado con bastante veracidad.

En el convento de Churubusco, cerca de la ciudad de México, se encuentran las estatuas de los fundadores. Pertenece este manasterio a la Orden de Franciscanos Descalzos de la Provincia de San Diego, por lo que se les conoce con el nombre de Dieguinos. Don Diego de Castillo y su mujer, doña Elena de la Cruz (Figs. 9, 10 y 11) "levantaron iglesia y convento desde los cimientos con gasto de sesenta mil pesos que se consumieron en la fábrica, dedicada en 2 de mayo de 1678 .

"Concluída iglesia y convento, Diego del Castillo siguió beneficiándolos con cuantiosas limosnas y subsiguientes obras, hasta su muerte, acaccida el 13 de marzo de 1683. Fué enterrado. en la iglesia de Churubusco, en el presbiterio, el dia 15."22

Las dos estatuas orantes se encontraban seguramente en el templo. En la actualidad, después de haber andado de la ceca a la meca, han sido instalados en sendos nichos en un ambulatorio del piso alto, a ambos lados de la puerta que da ingreso a una tribuna. El arreglo es bastante adecuado y pueden estudiarse detenidamente. $\mathrm{El}$ cabaliero viste jụbón $y$ calzas negros y cubre sus hombros un herreruelo. En el cuello lleva la

21 Tenancingo y el Santo Desierto de to monjes carmelitas. Por Enrique Juan Palacios. Boletín del Museo Nacional de Arqueologí, Historia y Etnografía. T. ri. No 5.

22 Ramón Menz y Nicolds Rangel. Churubusco. Fáges. 26-27. 
clásica golilla y su peinado se pone h moda de mediados del siglo xvil con cabello largo, bigotes espesos y una abundante piocha. Don Diego era calvo, conserva apenas un mechón sobre la frente; su rostro está vigorosamente tratado; los cabellos sin detalles y en toda la escultura se nota una estilización un tanto ruda. No conocemos cual haya sido su epitafio original, en la actualidad lleva una cartela que dice; "Don Diego del Castillo benefactor de este convento de San Diego. Churubusco, 1678."

La dama ostenta las manos cruzadils asimismo sobre el pecho, está vestida de negro con una amplita falda y grandes mangas con vueltas blancas también y su cuello es tn cuello valón que cae sobre los hombros y carece de ornato. Es una mujer gruesa, de labios carnosos; un poto sensual, que espera reposadamente el día de la resurrección.

En el mismo Museo de Churubusco existe una gran estatua orante en piedra que representa al patrono del convento de Sán Diego de Tacubaya. Está dorada sobre una capa de yeso; su técnica, un tanto ruda pero amplia y sincera, parece precursora de la de la escultura contemporánea. El caballero tiene las manos juntas, su cabello largo le cae sobre los hombros a la moda que se usó en la época de Carlos II; está vestido con jubón ceñido a la cintura y en uno de sus bolsillos tiene la llave, símbolo del patronato. Usa golilla (rota en parte); stus mangas, como sts calzones, son abullonados y a lo largo de estos se ve una botonadura; cae sobre sus espaldas una capa. Como obra de arte espontánea; quizís de mano indigena, esta estatua es notable. Rơnero de Termeros dice que se trata, según parece, de don Diego Suares de Peredo, en tanto que el señor don José de Agreda y Sánchez manifestó a mi estimado amigo Federico Gómez de Orozco que el caballero representado es don Diego de Agreda (Fig. 12) conde de igual título.

Dos de las estatuas funterarias más interesantes de 1a Nueva Espana stubsisten en la capilla de la Santa Casa de Loreto en la iglesia del Oratorio de' San Felipe Neri en la cíudad de San Miguel de Allende, Estado de viatiajuato. Fueron patronos de este instituto don Manuel Tomás; Conde de la Canal y su esposa doña María de Hervás y Flores (Figs, 13 y 14). Construyeron esta devota capilla con su camarin posterior que es una de las joyas arquitectónicas de esa ciudad. E1 conde murió el 15 de abril de 1749, tres dias despué que a esposa; ambos fueron enterrados en la ca- 
pilla y sus estatuas orantes se colocanoin en sendos nichos en ambos mutos del Evangelio y la Epístola. Aun existen alli, pero ed arreglo actual data de cuando fué restaurado el conjunta, es decir, de 1834. Asi puede verse que estos nichos son ya de estilo neoclásico en vez del barroco exuberante que deben haber ostentado los primitivos. El conde se haya vestido con su gran casaca, debajo de la cual aparece una especie de chupe; su corbata no parece la original pues está bastante maltratada; la mano izquierda sostiene una lémpara; la derecha está en actitud de apoyarse al frente. La fecha 1735 que se lee arriba corresponde a la construcción de la Santa Case y el camarín, soberbiamente esculpido. Mueve a la figura una graciosa inclinación de cabeza y la obra revela a un vigoroso artista. La estatuạ de la señora fervás y Flores es menos valiosa; está en la misna postura que su marido, con la mano izquierda al pecho y en la derecha una lámpara. Está vestida con un jubón de manga corta y una falda plegada y, sobre su cabello, una ligera túnica. El rostro es menos vigoroso; está bien construído pero, acaso por su carácter femenino, el relieve se suaviza un tanto, más que" en la cabeza del conde. La técrica es la misma en ambas estatuas. La fecha de 1834 que se ve arriba corresponde a la restauración como ya hemos dicho. ${ }^{28}$

El monumento sepulcral más bello que subsiste de la época del virreinato es, sin duda, el nicho con estatua orante que se conserva en la capilla de los Medina Picazo, en el templo de Regina, de la ciudad de México. Don Buenaventura de Medina Picazo (Figs. 15, 16 y 17) que recibió las órderies sagradas en 1682, fué hijo de doña Isabel Picazo de Hinestrosa y a su muerte fué enterrado en la capilla de la Purísima Concepción del templo de Regina, capilla que la sefiora Picazo había levantado a sus expensas.

La parte arquitectónica del edificio revela el estilo que floreció en México en la primera mitad del siglo xvirr; es una hornacina abierta en el muro, que descansa sobre una pequeña imposta de la que cuelgan cinco faldoncitos con relieves y borlas. La flanquean dos pilastras con sus traspilastras. En los recuadros de dichas pilastras hay relieves vegetales; los capiteles son corintios, de acantos; I2 hornacina esth cubierta por una concha cuyo perímetro se ve muy ornamentado; sobre las capiteles, un

23 Véage San Miguel de Allende, pot Francisco de la Maza. México. 1939. Pag. 56. 
rico entablamiento con su friso, cubierto todo de profundos relieves, sostíene una cornisa volada sobre la cual hay un frontón roto, curvilíneo, terminado en volutas y en el espacio libre que queda al centro, el escudo de armas de la familia.

La estatua orante muestra a un hombre entrado en afios, vestido con sotana y manteo, con su sombrero de teja al lado; está de rodillas sobre dos cojines y su proporción es un tanto defectuosa pues parece pequeña para la altura del nicho, o bien éste ha sido hecho para una estatua pedestre. A eso se debe quizá la abundancia de cojines. E1 verismo del rostro es notable, pues hasta un defecto de estrabismo se le nota. Por su conjunto, ya que se conserva no sólo la estatua, sino el nicho completo, este monumento es, como deciamos acaso el más importante que subsiste en la escultura funeraria de la época colonial.

Una de las áltimas esculturas funerarias que se hizo en la Nueva España, fué la del Conquistador. Bien sabido es que a sus restos, traídos de España, reposaron durante largo tiempo en el Monasterio de San Francisco de Texcoco y de alli fueron trasladados a esta capital para ser depositados en el Hospital de la Purísima Concepción que él fundara y que más tarde se intituló de Jesús Nazareno.

En 1792, por orden del Virrey, segundo Conde de Revillagigedo, se erigió el monumento sobre su sepulcro en el presbiterio de la igiesia de dicho Hospital. "Los restos del Conquistador se colocaron en una urna, adornada con su escudo de armas y coronada por el busto de don Hernando que descansaba sobre un amplio pedestal, en el cual se lee extensa inscripción o epitafio en castellano." 24

De acuerdo con la reproducción del sepulcro que publicamos (Fig. 18) y que figura en un plano de dicho monumento fechado en 1823 por Antonio Villar, el sepulcro presenta el aspecto siguiente: sobre un basamento o plinto se levanta una estructura que simula entablerado sobre la cual descansa una mesa de attar también entablerada. En el tablero superior no existe el epitafio extenso que menciona el señor Romero de Terreros, en él simplemente dice: "Aqui yace el gran héroe Hernando Cortés"; en el inferior se lee: "trasladado a este panteón el 2 de julio de 1794". Como se ve, hay contradicción con los datos que proporciona Romiero de Terreros; probabiemente el tnontmento fué empezado en ' 1792 ' y conciuido en 1794.

24 Romero de Tetreros, op. cit., pag. 75. 
Sobre la mesa de altar se levanta tuna urna con un escudo, cuyos emblemas no alcanzan a distinguirse pero que no parece ser el del Conquistador y sobre esa urna la estatua de busto, ceñido de armadura renacentista y cubierta en parte por un paño. La cabeza del héroe no puede tomarse como un retrato: si no fuera por la leyenda, imposible sería saber que se trataba de Cortés. Su indumentaria y su tocado más bien recuerdan a Enrique IV de Francia. En la parte posterior del busto se levanta un obelisco o pirámide a la moda que se usaba entonces. González Obregón dice que la parte arquitectónica fué obra de José del Mazo, según el diseño que se le dió y que el morumento estaba edificado con piedra de jaspe, sincotel o villeria y tecali y el busto fué ejectutado por don Manuel Tolsá en bronce y dorado a fuego. El arquitecto recibió mil quinientos cincuenta y cuatro pesos y el escultor mil quinientos.

Es indudable que la obra de Tolsá debe haber sido de mérito dado el gran talento escultórico del valenciano. Pero el monumento en sí revela una pobreza de imaginación $y$ de material bien indigna de los heroicos hechos de Cortés. En 1822 el sepulcro fué destruido y el escudo y el busto fueron remitidos a Palermo en donde vivia el Duque de Terranova, descendiente de Hernán Cortés. ${ }^{26}$

Las informaciones que hemos podido obtener y consignamos en este ensayo, revelan que el tema puede ser aún apurado y llegar a mayor perfección, asi por nuevas esculturas que se descubran, como por datos inéditos que aparezcan. Nos es pues grato colocar esta segunda piedra en el monumento que ha de labrarse: un capítulo más en la historia de nuestras artes plásticas. No podemos menos de imaginar la gran arquitectura mexicana del siglo Xvi, así en sus iglesias monásticas, como en las catedrales que entonces fueron comenzadas, sin un gran conjunto de esculturas marmóreas como las que ornamentan tantas iglesias españolas y que ha reseñado el señor Orueta. Suponemos, pues, que venciendo todas las dificultades, salvando todas las prohibiciones, se hizo un conjunto de esculturas que el tiempo ha destruido por las causas que hemos mencionado. Aun así, nuestras informaciones harán apreciar al lector los caracteres principales y los ejemplares que aun nos restan de la escultura funeraria de la Nueva España.

25 Romero de Terreros, op. cit. pág. 76. 


\section{B I B LIOGRA F I A}

AmGuto Ifiguez. Diego. Planos de América y Filipinas.

CERón ZAPATA, D. MIGUEL. Narración en dibuxo amoroso que ideó el afecto páricio del secretatio Dón Miguel Zerón Zapata, Escribano Mayor de Cabildo y Diputación de la Mug Noble y muy Leal Ciudad de los Angeles y Natario de la Sarta Inquisición. Puebla. 1926.

DE IA MazA. Francisco. San Miguel de Allende. México, 1939.

Gonzalez obrecón. Luis. Maxico Viejo. México, 1892.

LEICHT, DR. Hugo. Lus calfes de Puebla. Estudiò Fistórico. Puebla (México), 1934.

MENX. RAMÓN Y RANGel, Nrcolks. Churubusco. México.

ORUETA. RICARDO DE. La Escuttura funergria en España. Madrid, 1919.

Palacios, Enaique JuAN, Tenancingo y el Santo Desietto de los monjes Carmelitat. Boletín del Museo Nacional de Arqueología. Historia y Etnografia. Tomo II, núm. 5 .

RAMfrez APARICIo, Manuel. Los Conventos Suprimidos en México. Mexico, 1867.

RAMfrez DE VARGAS, ALONSo. Sagrado Padrón y panegyricos sermones . . en la dedicación del convento religioso del glorioso Abad San Bernardo. México, 1690.

Romero de Terreros. Manuel. Arte Colonial. Tercera serie. México, 1921.

VeYTia. LIC. D. MARIANo FERNANDEZ DE ECHEVERRIA. Y. Historia de la fundación de la ciudad de la Publa de los Angeles en la Nueva España. Puebla, 1931.2 vols. 